\title{
Highly stable Meldrum's acid derivatives for irreversible aqueous covalent modification of amines
}

\author{
Supporting Information
}

Garrett J. Davisł, Holly A. Sofkał, and John C. Jewett ${ }^{*}$

Department of Chemistry and Biochemistry, University of Arizona, Tucson, Arizona 85721, USA

\author{
*Email: jjewett@email.arizona.edu
}




\section{Table of Contents}

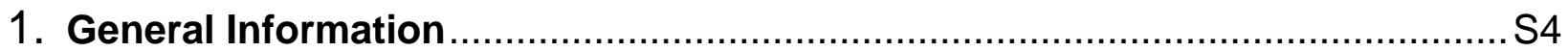

2. Synthetic Procedures and Characterization........................................................ S5

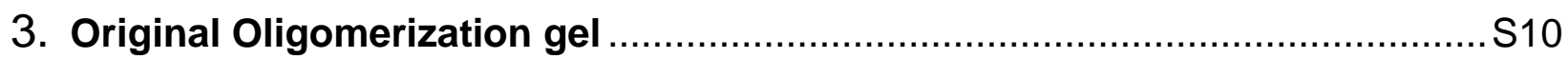

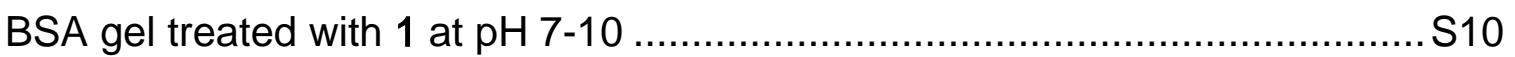

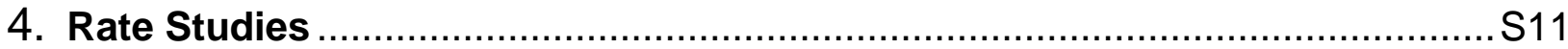

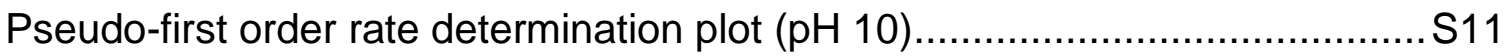

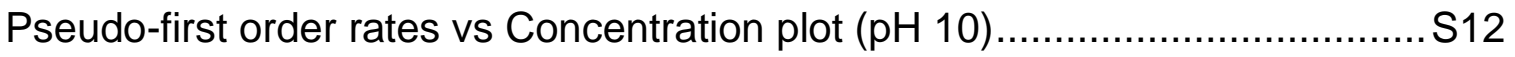

Exemplar absorbance scans for kinetic measurements $(\mathrm{pH} 10) \ldots \ldots \ldots \ldots \ldots \ldots \ldots . . . . . . . . . . .313$

Zoomed in absorbance scans for kinetic measurements $(\mathrm{pH} \mathrm{10) \ldots \ldots \ldots \ldots \ldots \ldots ....S14}$

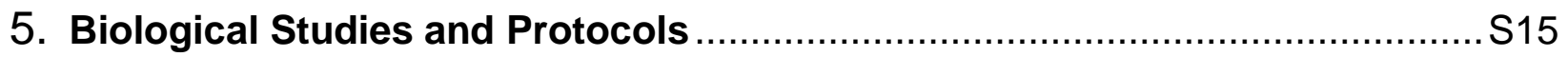

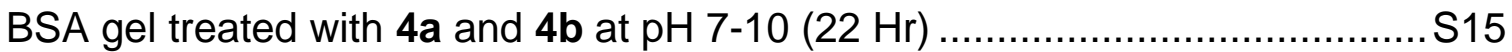

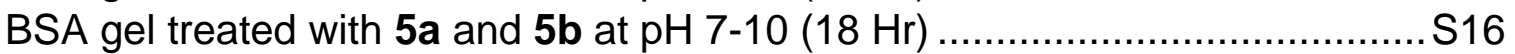

Quantification of BSA band fluorescence protocol.........................................S17

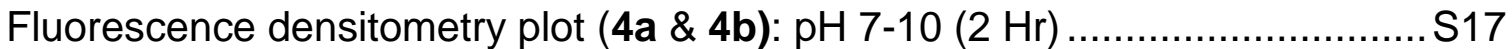

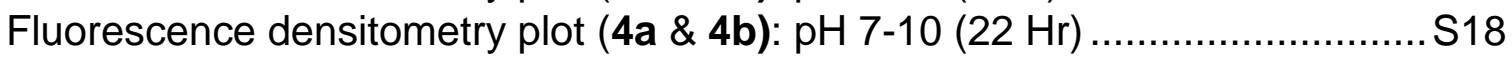

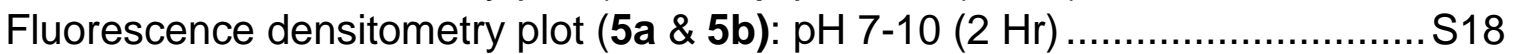

Fluorescence densitometry plot $(\mathbf{5 a} \& \mathbf{5 b}): \mathrm{pH} 7-10(18 \mathrm{Hr}) \ldots \ldots \ldots \ldots \ldots \ldots \ldots \ldots . . . . . . . . . . . . .19$

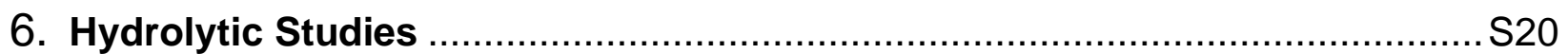

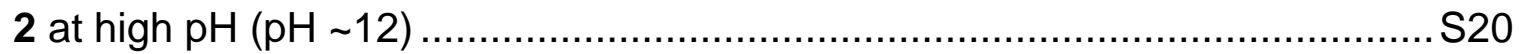

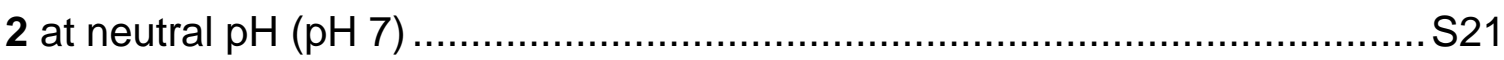

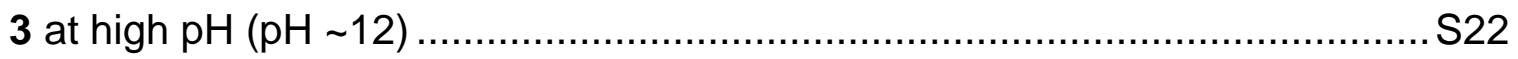

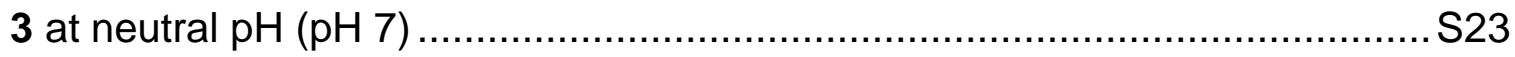

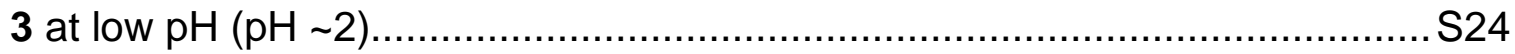

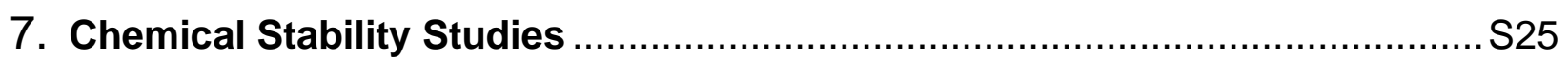

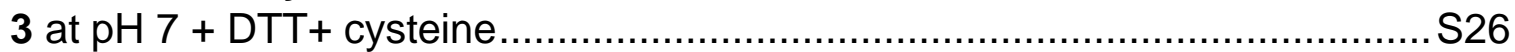

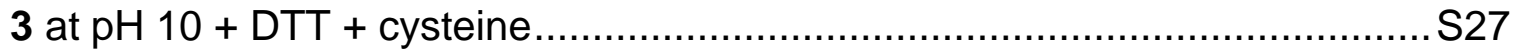

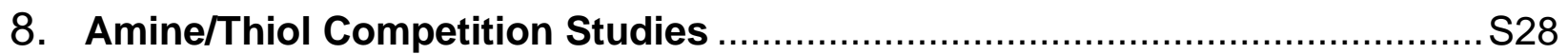

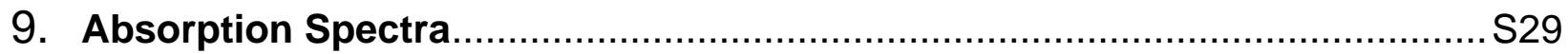

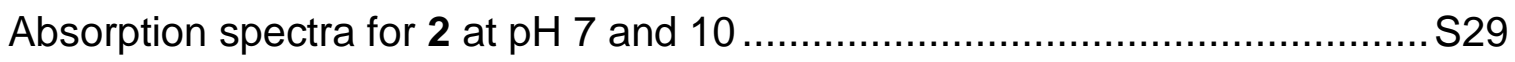

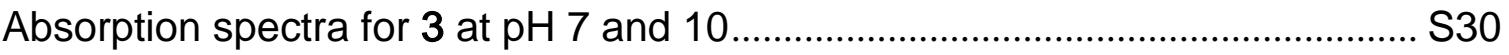




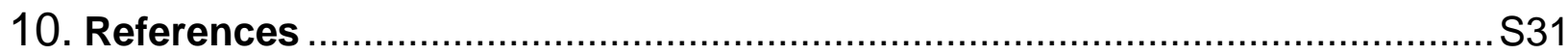

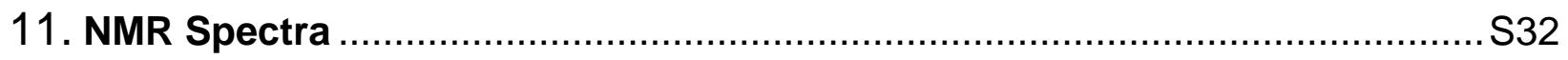




\section{General Information}

Meldrum's acid, carbon disulfide, methyl iodide, triethyl amine, propyl amine, propargyl amine, azido-PEG3-amine, 4-chloro-7-nitrobenzofurazan, boc anhydride, 1,3diaminopropane, and $\mathrm{N}$-acetylated cysteine, along with all solvents were all commercially purchased and used as received.

NMR spectra were taken on a Bruker AVIII-400 NMR Spectrometer for ${ }^{1} \mathrm{H}$ and ${ }^{13} \mathrm{C}$ NMR and referenced with residual solvent peaks at $7.26 \mathrm{ppm}$ and $77.05 \mathrm{ppm}$ for $\mathrm{CDCl}_{3}, 2.50$ and 39.52 for DMSO, and $4.79 \mathrm{ppm}$ for $\mathrm{D}_{2} \mathrm{O}$ respectively. Coupling on the NMR spectra is expressed in Hertz, chemical shifts in ppm, with abbreviations for multiplicities reported as $\mathrm{s}=$ singlet, $\mathrm{d}=$ doublet, $\mathrm{t}=$ triplet, $\mathrm{q}=$ quartet, $\mathrm{p}=$ pentet, $\mathrm{m}=$ multiplet. Mass spectra were obtained using a Thermo LTQ Orbitrap Velos with an ion trap mass analyzer. Absorbance spectra were obtained using an Agilent 8453 UV-visible spectroscopy system. Infrared spectra were obtained using a Thermo Fisher Scientific Nicolet IS50R FT-IR spectrometer equipped with an MCT-A detector and a germanium spectratech thunderdome ATR accessory with signals reported as $\mathrm{w}=$ weak, $\mathrm{br}=$ broad, $\mathrm{s}=$ strong. 


\section{Synthetic Procedures and Characterization}

General synthesis of single amine MaMa

To a solution of MaMa in a 5:1 ( $\mathrm{pH} 7$ PBS buffer:acetonitrile), amine was added (1 eq). The reaction was left to stir at room temperature for 24 hours. The reaction was concentrated down and the product was extracted with acetone.

General synthesis of symmetric double amine MaMa from 1

To a solution of MaMa in a 5:1 ( $\mathrm{pH} 10$ sodium borate buffer:acetonitrile), amine was added $(3 \mathrm{eq})$. The reaction was left to stir at room temperature for 24 hours. The reaction was concentrated down and extracted with acetone.

General synthesis of asymmetric double amine MaMa from single amine MaMa

To a solution of single amine MaMa in $5: 1 \quad(\mathrm{pH} 10$ sodium borate buffer:acetonitrile), amine was added (3 eq). The reaction was left to stir at room temperature for 24 hours. The reaction was concentrated down and extracted with acetone. 
5-(bis(methylthio)methylene)-2,2-dimethyl-1,3-dioxane-4,6-dione (1)

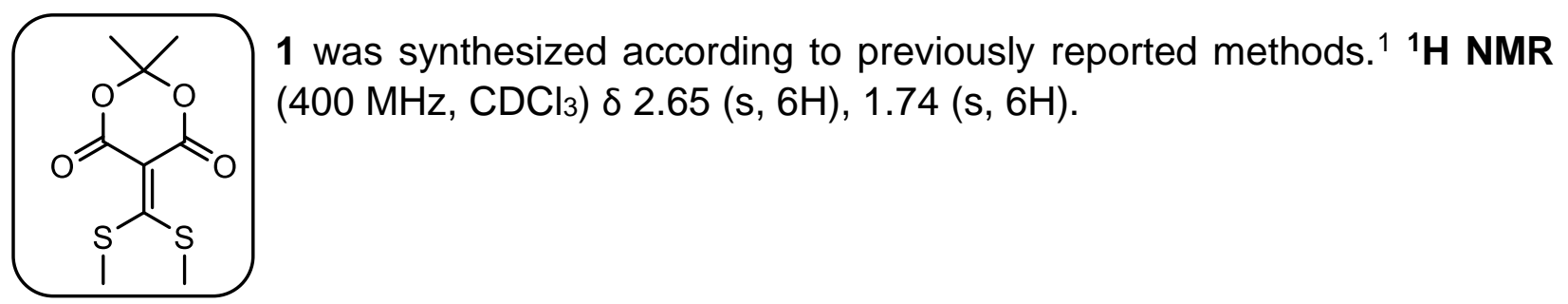

2,2-dimethyl-5-((methylthio)(propylamino)methylene)-1,3-dioxane-4,6-dione (2)

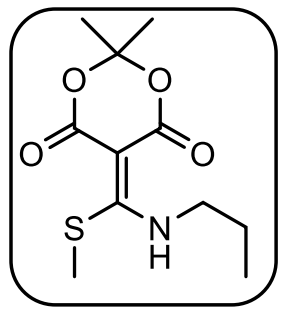
General synthesis for single amine addition to 1 was followed using 1 (0.08 $\mathrm{g}, 0.32$ mmoles) and propyl amine $(0.026 \mathrm{~mL}, 0.32$ mmoles) in $12 \mathrm{~mL}$ of $5: 1 \mathrm{pH} 7$ buffer:MeCN to isolate product as a pale yellow solid $(0.075 \mathrm{~g}$, $91 \%)$. Also completed on a 1.2 mmole scale, using 1 (0.30 g, 1.21 mmoles) and propyl amine (0.099 mL, 1.21 mmoles) in $30 \mathrm{~mL}$ of $5: 1 \mathrm{pH} 7$ buffer:MeCN in quantitative yields. ${ }^{1} \mathrm{H}$ NMR $\left(400 \mathrm{MHz}, \mathrm{CDCl}_{3}\right) \delta 11.01$ (bs, 1H), 3.56 (q, 2H), 2.57 (s, 3H), 1.74-1.71 (m, 8H), 1.02 (t, 3H). $\left.{ }^{13} \mathrm{C} \mathrm{NMR} \mathrm{(100} \mathrm{MHz,} \mathrm{CDCl}_{3}\right)$ $\delta$ 178.7, 163.9, 102.7, 83.0, 47.8, 26.8, 26.2, 22.6, 21.5, 18.4, 11.3. IR (ATR) 2970 (b), 2930 (b), 1710 (s), 1650 (s), 1570 (s), 1420 (w), 1380 (w), 1370 (s), 1270 (s), 1200 (s). HRMS (ESI) m/z: [M + H]+ Calcd for $\mathrm{C}_{11} \mathrm{H}_{17} \mathrm{NO}_{4} \mathrm{SH} 260.0956$; Found 260.0951 .

5-(bis(propylamino)methylene)-2,2-dimethyl-1,3-dioxane-4,6-dione (3)

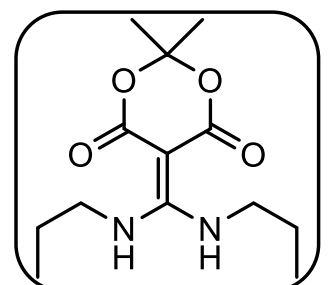

General synthesis of symmetric double amine MaMa from 1 was followed using 1 (0.040g, 0.16 mmoles) and propyl amine $(0.020 \mathrm{~mL}$, $0.48 \mathrm{mmoles}$ ) in $6 \mathrm{~mL}$ of $5: 1 \mathrm{pH} 10$ buffer:MeCN. Isolated product was a light brown solid $(0.039 \mathrm{~g}, 92 \%)$. ${ }^{1} \mathrm{H}$ NMR $\left(400 \mathrm{MHz}, \mathrm{CDCl}_{3}\right) \delta 9.81$ (bs, $2 \mathrm{H}), 3.37$ (q, 4H), 1.73-1.65 (m, 10H). $1.01(\mathrm{t}, 6 \mathrm{H}) .{ }^{13} \mathrm{C}$ NMR $(100$ $\left.\mathrm{MHz}, \mathrm{CDCl}_{3}\right) \delta$ 166.7, 163.9, 102.0, 74.0, 47.3, 26.1, 23.4, 11.2. IR (ATR) 2950 (b), 2870 (b), 1650 (s), 1570 (w), 1460 (w), 1450 (w), 1390 (s), 1360 (s), 1310 (w) 1260 (w). HRMS (ESI) $\mathrm{m} / \mathrm{z}:[\mathrm{M}+\mathrm{H}]+$ Calcd for $\mathrm{C}_{13} \mathrm{H}_{22} \mathrm{~N}_{2} \mathrm{O}_{4} \mathrm{H}$ 271.1658; Found 271.1652. 
5-(15-azido-7,10,13-trioxa-2-thia-4-azapentadecan-3-ylidene)-2,2-dimethyl1,3-dioxane-4,6-dione (4a)

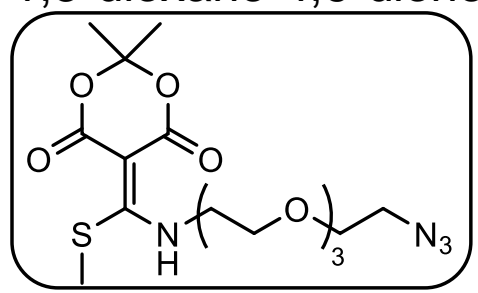

General synthesis of single amine addition to 1 was followed using 1 (0.050 g, 0.20 mmoles) and azido-PEG3-amine $(0.04$ $\mathrm{mL}, 0.201$ mmoles) in $7.5 \mathrm{~mL}$ of $5: 1 \mathrm{pH} 7$ buffer:MeCN to isolate product as brown oil in quantitative yields. ${ }^{1} \mathbf{H}$ NMR $(400$ $\left.\mathrm{MHz}, \mathrm{CDCl}_{3}\right) \delta 11.14(\mathrm{bs}, 1 \mathrm{H}), 3.78(\mathrm{q}, 2 \mathrm{H}), 3.73(\mathrm{q}, 2 \mathrm{H}), 3.67-$ $3.64(\mathrm{~m}, 10 \mathrm{H}), 3.37(\mathrm{t}, 2 \mathrm{H}), 2.55(\mathrm{~s}, 3 \mathrm{H}), 1.70(\mathrm{~s}, 6 \mathrm{H}) .{ }^{13} \mathrm{C} \mathrm{NMR}\left(100 \mathrm{MHz}, \mathrm{CDCl}_{3}\right) \delta 178.6$, 163.8, 102.6, 83.4, 70.8, 70.7, 70.7, 70.6, 70.0, 68.6, 50.7, 45.9, 41.0 26.2, 18.4. IR (ATR) 2870 (b), 2100 (s), 1710 (s), 1650 (s), 1560 (s), 1440 (w), 1390 (s), 1320 (s), 1290 (s), 1200 (s). HRMS (ESI) m/z: [M + H]+ Calcd for $\mathrm{C}_{16} \mathrm{H}_{26} \mathrm{~N}_{4} \mathrm{O}_{7} \mathrm{SH} 419.1600$; Found 419.1603.

5-(1-azido-3,6,9-trioxa-12,14-diazaheptadecan-13-ylidene)-2,2-dimethyl1,3-dioxane-4,6-dione (4b)

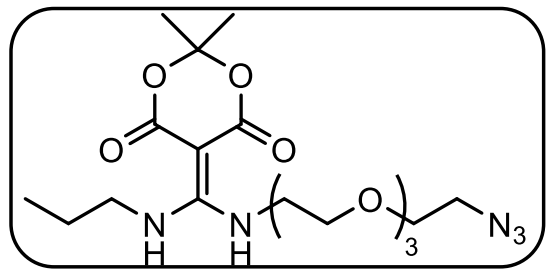

General synthesis of asymmetric double amine MaMa from 4a $(0.169 \mathrm{~g}, 0.40 \mathrm{mmoles})$ and propyl amine $(0.01 \mathrm{~mL}, 1.21$ mmoles) in $15 \mathrm{~mL}$ of $5: 1 \mathrm{pH} 10$ buffer:MeCN to isolate product as light brown oil in quantitative yields. ${ }^{1} \mathbf{H}$ NMR $\left(400 \mathrm{MHz}, \mathrm{CDCl}_{3}\right) \delta 9.96$ (bs, $\left.1 \mathrm{H}\right), 9.79(\mathrm{bs}, 1 \mathrm{H}), 3.69-3.61$ $(\mathrm{m}, 12 \mathrm{H}), 3.58(\mathrm{q}, 2 \mathrm{H}), 3.38-3.32(\mathrm{~m}, 4 \mathrm{H}), 1.72-1.61(\mathrm{~m}, 8 \mathrm{H}), 0.98,(\mathrm{t}, 3 \mathrm{H}) .{ }^{13} \mathrm{C}$ NMR $(100$ $\left.\mathrm{MHz}, \mathrm{CDCl}_{3}\right) \delta 166.5,164.1,102.0,74.0,70.9,70.8,70.7,70.6,70.6,70.0,69.6,50.7$, 47.3, 45.2, 26.1, 23.4, 11.2. IR (ATR) 2920 (b), 2870 (b), 2100 (b), 1660 (s), 1450 (w), 1400 (s), 1370 (w) 1310 (w), 1260 (w), 1210 (w). HRMS (ESI) m/z: [M + H]+ Calcd for $\mathrm{C}_{18} \mathrm{H}_{31} \mathrm{~N}_{5} \mathrm{O}_{7} \mathrm{H} 430.2301$; Found 430.2296

Boc-1,3-diamine (standard procedure) (S1)<smiles>CC12CCCC(CC1)C2</smiles>

$1.18(\mathrm{~s}, 2 \mathrm{H})$.
Boc-1,3-diaminopropane was synthesized according to previously reported methods. ${ }^{2}{ }^{1} \mathrm{H}$ NMR $\left(400 \mathrm{MHz}, \mathrm{CDCl}_{3}\right) \delta 5.11$ (bs, 1H), $3.12(\mathrm{~m}, 2 \mathrm{H}), 2.67(\mathrm{t}, 2 \mathrm{H}), 1.52(\mathrm{p}, 2 \mathrm{H}), 1.35(\mathrm{~s}, 9 \mathrm{H})$, 
tert-butyl (3-((7-nitrobenzo[c][1,2,5]oxadiazol-4-yl)amino)propyl)carbamate

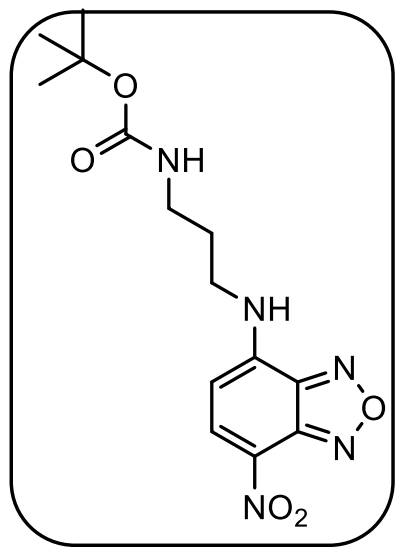

(S2)

S2 was synthesized from modified procedures, adding 4-chloro-7nitrobenzofurazan $(0.250 \mathrm{~g}, 1.25 \mathrm{mmoles}), \mathbf{S 1}$ (0.218 g, 1.25 mmoles), triethylamine $(0.314 \mathrm{~mL}, 2.25$ mmoles $)$ in $15 \mathrm{~mL}$ methanol. ${ }^{3,4}$ Product was used without further purification. ${ }^{1} \mathrm{H}$ NMR (400 MHz, CDCl 3$) \delta 8.48(\mathrm{~d}, 1 \mathrm{H}), 6.19(\mathrm{~d}, 1 \mathrm{H}), 4.93(\mathrm{bs}, 1 \mathrm{H}), 3.62$ (bs, 1H), $3.31(\mathrm{q}, 2 \mathrm{H}), 1.92(\mathrm{p}, 2 \mathrm{H}), 1.46(\mathrm{~s}, 9 \mathrm{H})$.

3-((7-nitrobenzo[c][1,2,5]oxadiazol-4-yl)amino)propan-1-aminium chloride

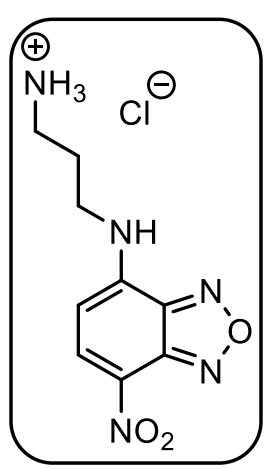

(S3)

S2 $(0.407 \mathrm{~g}, 1.21 \mathrm{mmoles})$ was stirred in a $1 \mathrm{M} \mathrm{HCl}$ in diethyl ether mixture $(20 \mathrm{~mL})$ for 3 hours. Reaction was concentrated and solid was washed with chloroform, resulting in an orange solid $(0.244 \mathrm{~g}, 71 \%$ over two steps). ${ }^{5}{ }^{1} \mathrm{H}$ NMR $\left(400 \mathrm{MHz}, \mathrm{D}_{2} \mathrm{O}\right) \delta 8.47(\mathrm{~d}, 1 \mathrm{H}), 6.37(\mathrm{~d}, 1 \mathrm{H}), 3.72$ (bs, $2 \mathrm{H}), 3.21(\mathrm{t}, 2 \mathrm{H}), 2.20(\mathrm{p}, 2 \mathrm{H})$.

2,2-dimethyl-5-((methylthio)((3-((7-nitrobenzo[c][1,2,5]oxadiazol-4yl)amino)propyl)amino)methylene)-1,3-dioxane-4,6-dione (5a)

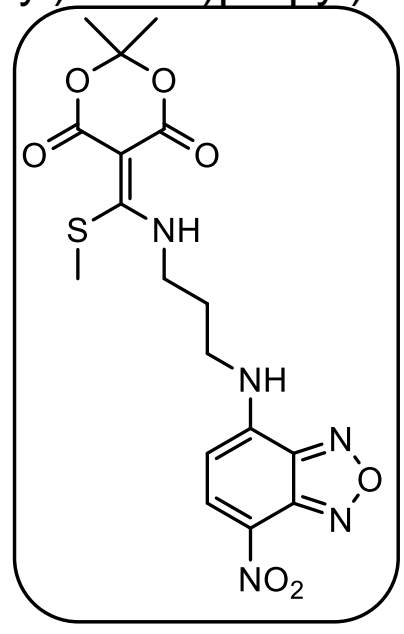

General synthesis of single amine addition to 1 was followed using 1 (0.080 g, 0.32 mmoles) and S3 (0.088 g, 0.322 mmoles) in $12 \mathrm{~mL}$ of $5: 1 \mathrm{pH} 7$ buffer:MeCN, resulting in orange solid purified after washing solid with methanol $(0.086$ g, 61\%). ${ }^{1} \mathrm{H}$ NMR $\left(400 \mathrm{MHz}, \mathrm{CDCl}_{3}\right) \delta 11.17$ (bs, $\left.1 \mathrm{H}\right), 8.51$ (d, $1 \mathrm{H}), 6.39(\mathrm{bs}, 1 \mathrm{H}), 6.25(\mathrm{~d}, 1 \mathrm{H}), 3.84(\mathrm{q}, 2 \mathrm{H}), 3.68(\mathrm{q}, 2 \mathrm{H})$, $2.60(\mathrm{~s}, 3 \mathrm{H}), 2.25(\mathrm{p}, 2 \mathrm{H}), 1.73(\mathrm{~s}, 6 \mathrm{H}) .{ }^{13} \mathrm{C}$ NMR $(100 \mathrm{MHz}$, DMSO) $\delta 179.4,162.8,145.5,144.9,144.5,121.4,114.3$, 102.4, 99.6, 82.7, 43.9, 41.0, 31.1, 27.6, 26.3, 17.9. IR (ATR) 2930 (b), 2850 (b), 1690 (w), 1650 (s), 1580 (s), 1560 (s), 1530 (w), 1500 (w), 1440 (w), 1390 (s), 1300 (s), 1280 (s). HRMS (ESI) m/z: $[\mathrm{M}+\mathrm{H}]+$ Calcd for $\mathrm{C}_{17} \mathrm{H}_{19} \mathrm{~N}_{5} \mathrm{O}_{7} \mathrm{SH} 438.1083$; Found 438.1078 . 
2,2-dimethyl-5-(((3-((7-nitrobenzo[c][1,2,5]oxadiazol-4yl)amino)propyl)amino)(propylamino)methylene)-1,3-dioxane-4,6-dione (5b)

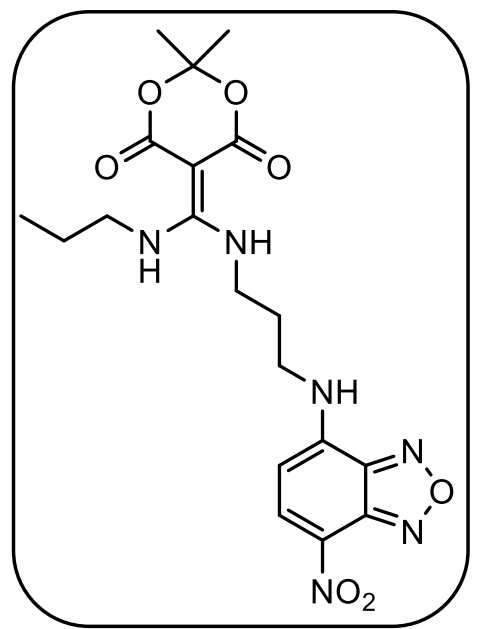

General synthesis of asymmetric double amine MaMa was made from $5 \mathrm{a}(0.015 \mathrm{~g}, 0.034 \mathrm{mmoles})$ and propyl amine ( $0.008 \mathrm{~mL}, 0.102$ mmoles) in $2.3 \mathrm{~mL}$ of $5: 1 \mathrm{pH} 10$ buffer:MeCN, resulting in orange solid in quantitative yields. ${ }^{1} \mathbf{H}$ NMR $(500$ $\mathrm{MHz}, \mathrm{DMSO}) \delta 9.36(\mathrm{bs}, 2 \mathrm{H}), 8.25(\mathrm{~d}, 1 \mathrm{H}), 5.77(\mathrm{~d}, 1 \mathrm{H}), 3.36$ $(\mathrm{m}, 6 \mathrm{H}), 1.82(\mathrm{p}, 2 \mathrm{H}), 1.55(\mathrm{~s}, 6 \mathrm{H}), 1.54(\mathrm{~m}, 2 \mathrm{H}), 0.91$ (t, 3H) ${ }^{13} \mathrm{C}$ NMR $(125.5 \mathrm{MHz}$, DMSO) $\delta 165.4,158.3,155.8,138.3$, 111.5, 101.9, 71.5, 40.3, 40.1, 40.0, 38.3, 26.0, 19.0, 11.3. IR (ATR) 2950 (b), 2850 (b), 2400 (b), 1770 (w), 1650 (w), 1640 (w), 1400 (w), 1350 (s), 1140 (s), 1060 (s). HRMS (ESI) m/z: $[\mathrm{M}+\mathrm{H}]+$ Calcd for $\mathrm{C}_{19} \mathrm{H}_{24} \mathrm{~N}_{6} \mathrm{O}_{7} \mathrm{H}$ 449.1784; Found 449.1779.

$\mathrm{N}$-acetyl-S-((2,2-dimethyl-4,6-dioxo-1,3-dioxan-5-ylidene)(propylamino) methyl)cysteine (S4)

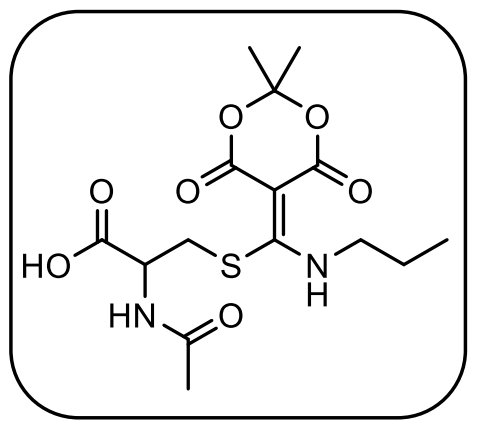

S4 was synthesized by dissolving $\mathrm{N}$-acetylated cysteine $(0.020$ $\mathrm{g}, 0.077 \mathrm{mmoles})$ and $2(0.013 \mathrm{~g}, 0.077 \mathrm{mmoles})$ in $2.9 \mathrm{~mL}$ of a $5: 1 \mathrm{pH} 10$ buffer:MeCN solution. Solution was stirred at $50^{\circ} \mathrm{C}$ for 42 hours. Solution was acidified to $\mathrm{pH} 7$ and extracted with $5 \mathrm{~mL}$ of DCM 2 times. The aqueous layer was then acidified to $\mathrm{pH} 1$ and extracted with $5 \mathrm{~mL}$ of DCM 2 times. The organic layer was dried over sodium sulfate and concentrated down, resulting in a white solid that was used without further purification. ${ }^{1} \mathrm{H}$ NMR $\left(400 \mathrm{MHz}, \mathrm{CDCl}_{3}\right) \delta 11.37$ (bs, $\left.1 \mathrm{H}\right), 7.79$ (bs, $\left.1 \mathrm{H}\right), 4.72(\mathrm{q}, 1 \mathrm{H}), 3.66$ $(\mathrm{m}, 2 \mathrm{H}), 3.49(\mathrm{dd}, 1 \mathrm{H}), 3.41(\mathrm{dd}, 1 \mathrm{H}), 2.11(\mathrm{~s}, 3 \mathrm{H}), 1.73(\mathrm{~m}, 8 \mathrm{H}), 1.04(\mathrm{t}, 3 \mathrm{H}) .{ }^{13} \mathrm{C} \mathrm{NMR}$ $\left(100 \mathrm{MHz}, \mathrm{CDCl}_{3}\right) \delta$ 174.9, 172.7, 164.8, 103.4, 84.8, 48.6, 37.0, 29.3, 26.4, 22.9, 11.4. 


\section{Original Oligiomerization Gel}

\section{$B S A$ treatment with 1 at various $\mathrm{pH}$}

A $1 \mathrm{mM}$ BSA stock was made in $1 \mathrm{~mL}$ of nanopure water. $50 \mu \mathrm{L}$ of stock BSA was added to each sample containing $890 \mu \mathrm{L}$ of appropriate buffer of $0.1 \mathrm{M} \mathrm{PBS} \mathrm{pH} \mathrm{7,8,9}$ or 10. To this solution was added $60 \mu \mathrm{L}$ of $100 \mathrm{mM} 1$ (24.8 $\mathrm{mg}$ in $1 \mathrm{~mL}$ DMSO). An additional control sample containing $50 \mu \mathrm{L}$ BSA and $890 \mu \mathrm{L}$ of PBS 7 and $60 \mu \mathrm{L}$ of DMSO was made to mimic the conditions void of compound 1. Samples were incubated at $25 \circ \mathrm{C}$ for 24 hours. Samples were then loaded on to a $12 \%$ SDS gel and analyzed by gel electrophoresis. The gel was stained with Coomassie and scanned on BioRad gel imaging instrument.

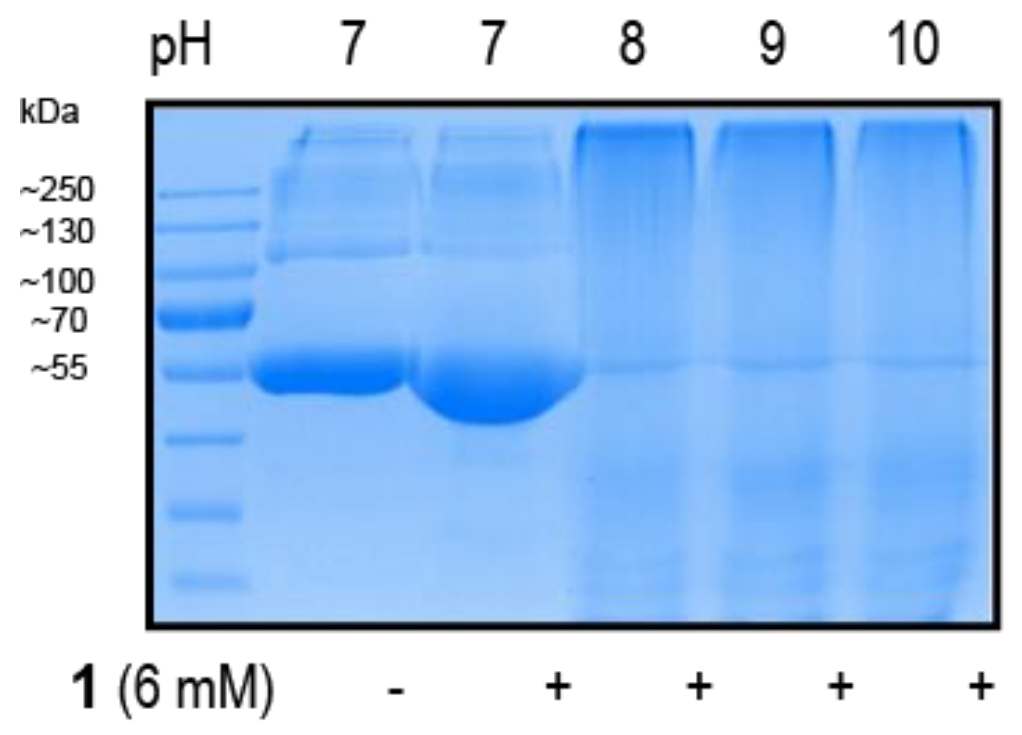

Figure S1. $50 \mu \mathrm{M}$ BSA treated with $6 \mathrm{mM} 1$ with increasing $\mathrm{pH}(7,8,9$ and 10) for 24 hours compared to nontreated $\mathrm{BSA}$ at $\mathrm{pH}$ 7. Band loss and increase in molecular weight is noted at $\mathrm{pH} 8$ and higher and attributed to oligomerization of BSA via lysine crosslinking through double addition to compound 1. 


\section{Rate Studies}

\section{General Procedures}

A $1 \mathrm{mg} / \mathrm{mL}$ stock of 2 was made in DMSO, along with a $1 \mathrm{M}$ stock of propyl amine in respective pH buffers (0.5 M PBS 7 and 8; $0.2 \mathrm{M}$ Borate 9 and 10). The stock of 2 was then diluted by taking $25 \mu \mathrm{L}$ of the original stock in $3975 \mu \mathrm{L}$ of corresponding $\mathrm{pH}$ buffers. Absorbance measurements were then completed by first taking an initial scan of $1 \mathrm{~mL}$ of the diluted 2 and then immediately spiking in $2 \mu \mathrm{L}$ of the propyl amine stock $(1 \mathrm{M})$. Absorbance values were obtained every 4 minutes for 1 hour for each $\mathrm{pH}$. Trials were completed in triplicate.

To obtain pseudo-first order rates, we monitored absorbance using the same concentration of 2 , but altered the concentration of the $2 \mu \mathrm{L}$ of propyl amine added (0.6 $\mathrm{mM}, 0.8 \mathrm{mM}, 1 \mathrm{mM}, 2 \mathrm{mM}, 4 \mathrm{mM})$. Scans were taken every 30 seconds for 20 minutes. Pseudo-first order rates were obtained by plotting the $\ln$ (absorbance) vs. time(s). These pseudo-first order rates were then plotted against the propyl amine concentration to find the second order rate.

\begin{tabular}{|r|r|r|}
\hline Concentration of Propyl Amine (M) & \multicolumn{1}{c|}{ Slopes } & Uncertainty \\
\hline 0.004 & $4.73 \mathrm{E}-04$ & $6.79 \mathrm{E}-06$ \\
\hline 0.002 & $3.05 \mathrm{E}-04$ & $2.69 \mathrm{E}-06$ \\
\hline 0.001 & $7.42 \mathrm{E}-05$ & $1.32 \mathrm{E}-06$ \\
\hline 0.0008 & $4.25 \mathrm{E}-05$ & $1.50 \mathrm{E}-06$ \\
\hline 0.0006 & $2.85 \mathrm{E}-05$ & $1.66 \mathrm{E}-06$ \\
\hline
\end{tabular}

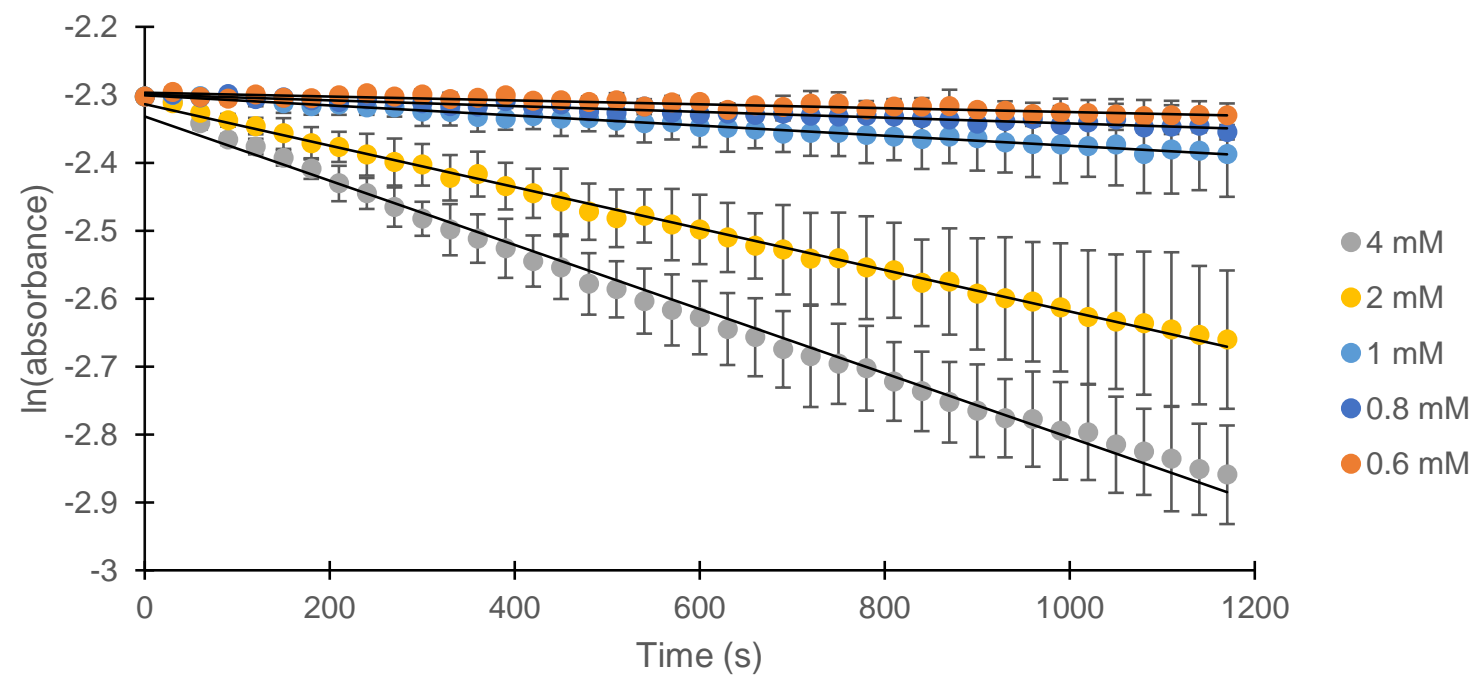

FigureS2: In(absorbance) plotted against time (s) (Top) to obtain pseudo-first order rates (slopes) along with tabulated values (Bottom). 


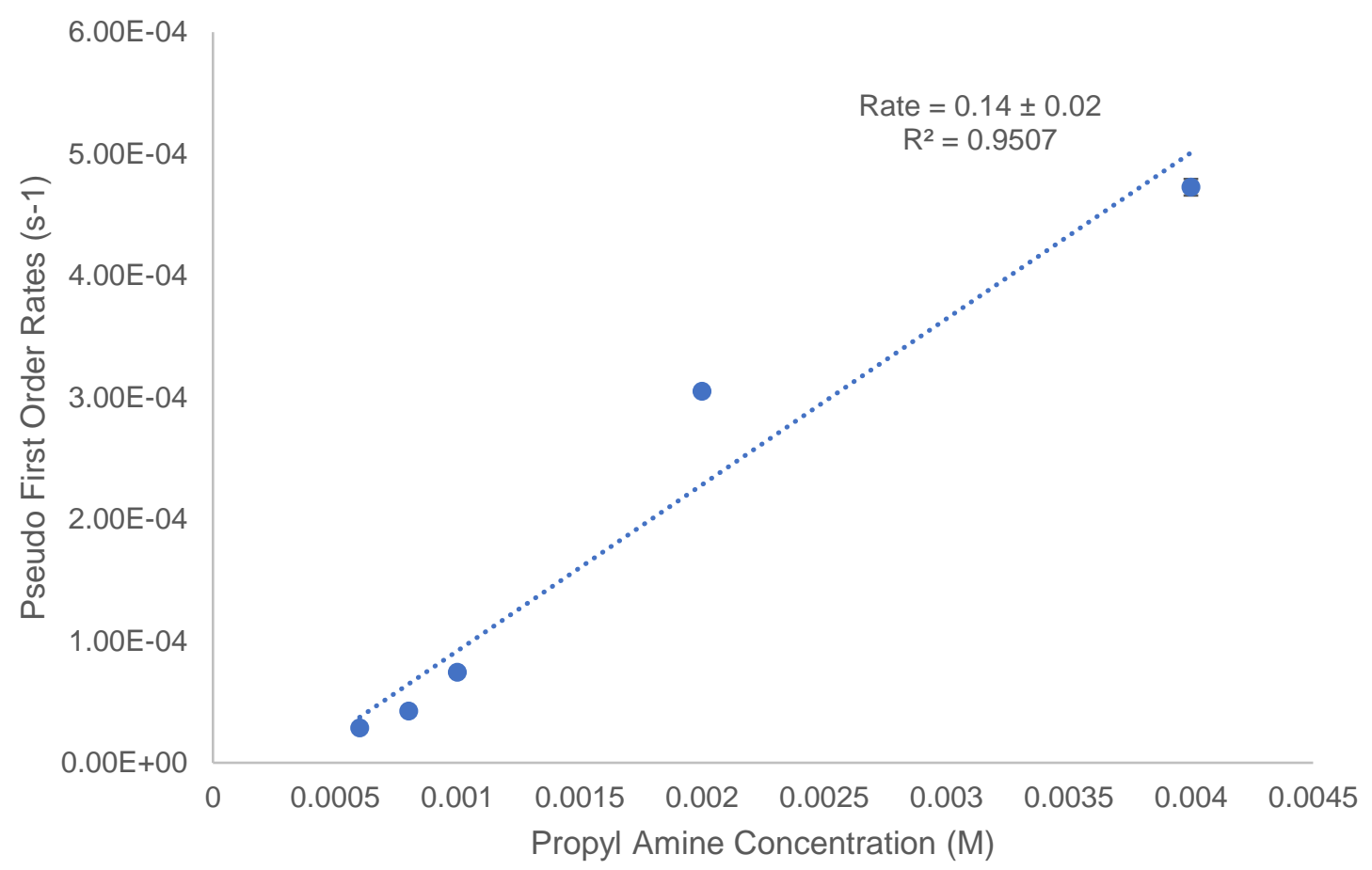

Figure S3: The pseudo-first order rates plotted against various propyl amine concentrations to find the second order rate (slope). 
Absorbance spectra for conversion of 2 to 3 at 10

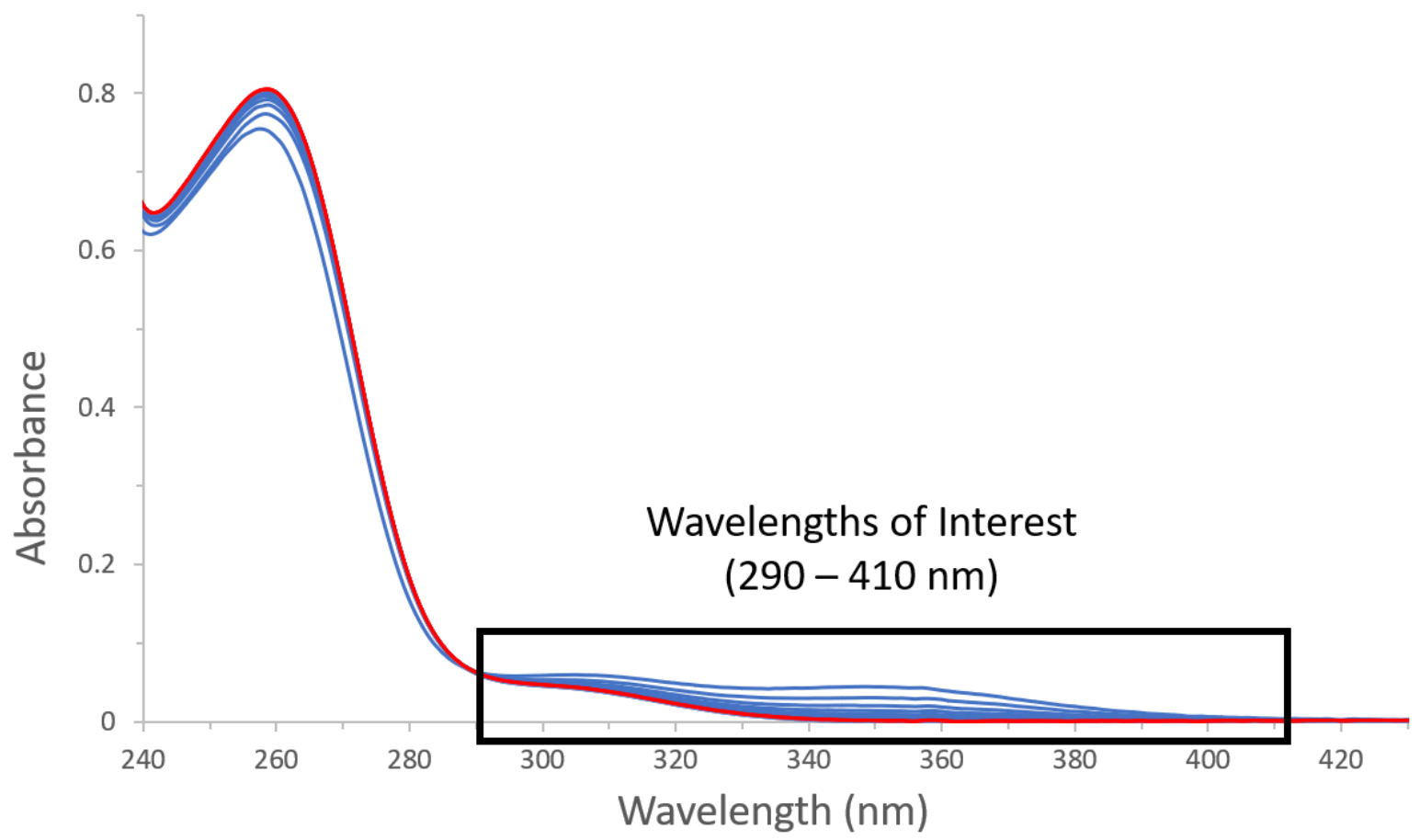

Figure S4: Overlaid absorbance spectra for conversion of 2 to $\mathbf{3}$ monitored on kinetic mode. Peak changes associated with conversion from 2 to $\mathbf{3}$ monitored at wavelengths 290-410 nm. 
Zoomed in absorbance spectra for conversion of 2 to 3 at 10

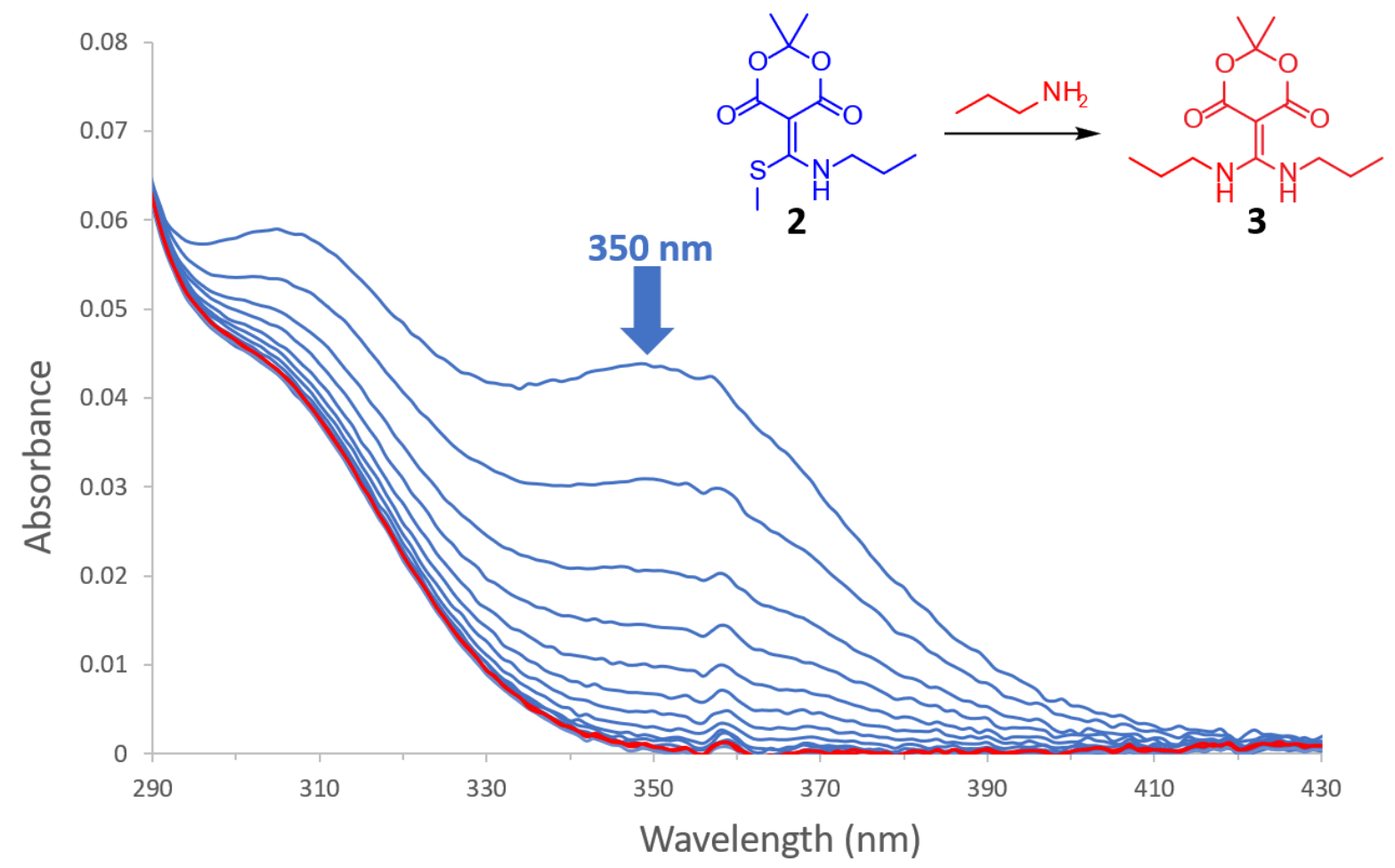

Figure S5: Overlaid absorbance spectra for conversion of 2 to 3 monitored on kinetic mode zoomed in to 290-430 nm. Conversion of 2 to $\mathbf{3}$ was monitored by loss of shoulder peak at $350 \mathrm{~nm}$ (blue) over time. Complete conversion to $\mathbf{3}$ is showed by complete loss of $350 \mathrm{~nm}$ peak (red). 


\section{Biological Studies and Protocols}

\section{$B S A$ treatment with $\mathbf{4 a}$ and $\mathbf{4 b}-2$ and 22 hour treatment}

Solutions of $50 \mu \mathrm{M}$ BSA were made by addition of $21.4 \mu \mathrm{L}$ a $1.2 \mathrm{mM}$ stock of BSA into $474.4 \mu \mathrm{L}$ of appropriate buffer. For solutions at pH 7 and 8 we used $100 \mathrm{mM}$ PBS and for solutions at $\mathrm{pH} 9$ and 10 we used $100 \mathrm{mM}$ Sodium Borate buffer. BSA samples were then treated with $0.5 \mathrm{mM} 4 \mathrm{a}$ via addition of $4.2 \mu \mathrm{L}$ of a $60 \mathrm{mM}$ stock solution $(2.5 \mathrm{mg} /$ $100 \mu \mathrm{L}$ DMSO). Control samples were treated with $0.5 \mathrm{mM} 4 \mathrm{~b}$ via addition of $4.2 \mu \mathrm{L}$ of $60 \mathrm{mM}$ stock (\#) (2.6 mg/ $100 \mu \mathrm{L}$ DMSO). Samples were then incubated void of light at $25 \stackrel{\circ}{ }$ C. After initial 2 hours, $250 \mu \mathrm{L}$ of each sample was transferred to new Eppendorf and then samples were quenched via addition of $5 \mu \mathrm{L}$ of $0.5 \mathrm{M}$ lysine to make a final concentration of $9.8 \mathrm{mM}$ lysine. The lysine stock was made by dissolving $18 \mathrm{mg}$ of lysine into $250 \mu \mathrm{L}$ of $1 \mathrm{M} \mathrm{HCl}$ solution. Samples were then adjusted to $\mathrm{pH}$ 7. The remaining $250 \mu \mathrm{L}$ of sample was let react for 22 hours and then quenched with $9.8 \mathrm{mM}$ lysine stock. Samples were subsequently treated with $50 \mu \mathrm{M}$ Cy3 cyclooctyne (DBCO) for 6 hours at room temperature.

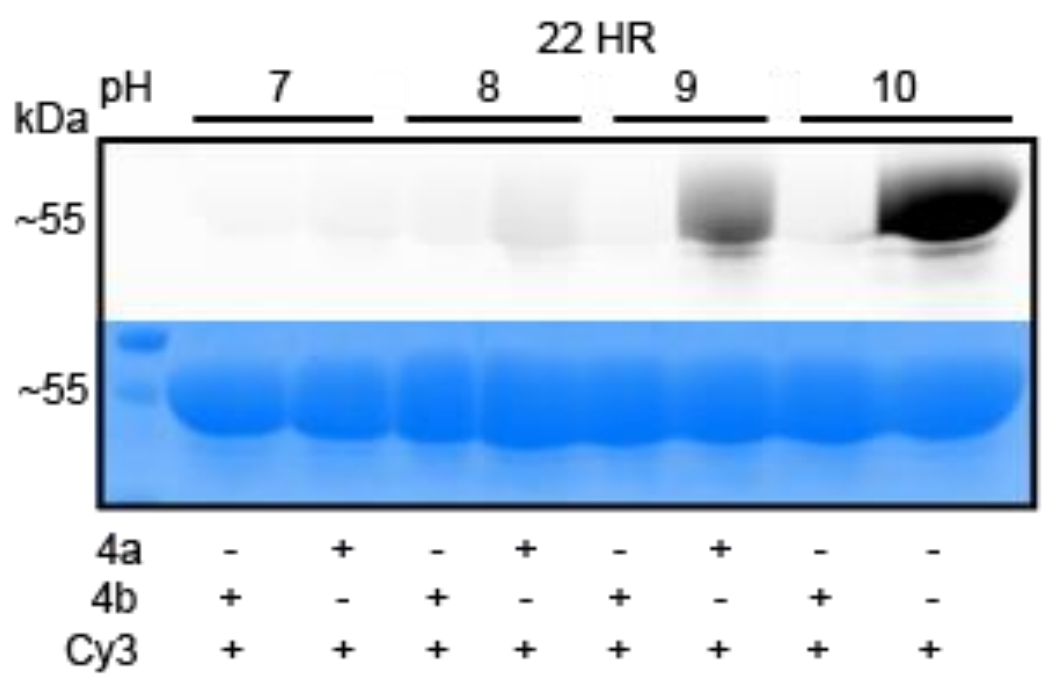

Figure S6. BSA labeled with $0.5 \mathrm{mM}$ compound 4a with increasing $\mathrm{pH}(7,8,9$ and 10$)$ for 22 hours compared to BSA treated with $0.5 \mathrm{mM}$ of nonreactive $\mathbf{4 b}$. All samples were further treated with a Cy3 cyclooctyne (DBCO) to yield fluorescence signal on modified samples. Fluorescence is seen increasing at high $\mathrm{pH}$ ( 9 and 10) with highest at 10 , consistent with kinetic rates that suggest highest rate of double addition at $\mathrm{pH} \sim 9.8$. 
Gel electrophoresis of $\mathbf{4 a}$ and $\mathbf{4 b}$ treated samples -2 and 22 hour treatment

$20 \mu \mathrm{L}$ of each sample was mixed with $20 \mu \mathrm{L}$ of $2 X$ Laemmli sample buffer and vortexed. Samples were loaded on a $4 \%-12 \%$ SDS gel and fluorescence analyzed by electrophoresis using a Cy3 excitation and emission laser line (535/545nm).

\section{$B S A$ treatment with $\mathbf{5 a}$ and $\mathbf{5 b}-2$ and 18 hour treatment}

A stock solution of $5 \mathrm{a}(\mathrm{MW}: 437 \mathrm{~g} / \mathrm{mol}$ ) was made by dissolving $6.5 \mathrm{mg}$ in $250 \mu \mathrm{L}$ of DMSO to make a $60 \mathrm{mM}$ solution. A second stock of control compound $5 \mathbf{b}$ was also made by dissolving $6.5 \mathrm{mg}$ of solid in to $250 \mu \mathrm{L}$ of DMSO. In $1.6 \mathrm{~mL}$ Eppendorfs, $25 \mu \mathrm{L}$ of $1 \mathrm{mM} \mathrm{BSA}$ was added to $467 \mu \mathrm{L}$ of the appropriate buffer of $\mathrm{pH} 7,8,9$, or 10 to provide two sets of samples with a final concentration of $50 \mu \mathrm{M}$ protein. $\mathrm{pH} 7$ and 8 buffers were composed of $0.1 \mathrm{mM}$ PBS and $\mathrm{pH} 9$ and 10 were composed of $0.1 \mathrm{mM}$ Borate buffer. One set of samples was treated with $8.33 \mu \mathrm{L}$ of $60 \mathrm{mM}$ control compound $\mathbf{5 b}$, while the other set was treated with $8.33 \mu \mathrm{L}$ of $\mathbf{5 a}$ yielding a final concentration of 1 $\mathrm{mM}$ of treatment. Samples were let react void of light at $25 \circ \mathrm{O}$ for 2 hours when $250 \mu \mathrm{L}$ of each sample was transferred to new Eppendorf and then samples were quenched via addition of $5 \mu \mathrm{L}$ of $0.5 \mathrm{M}$ lysine to make a final concentration of $9.8 \mathrm{mM}$ lysine. The remaining $250 \mu \mathrm{L}$ was quenched after 18 hours of incubation.

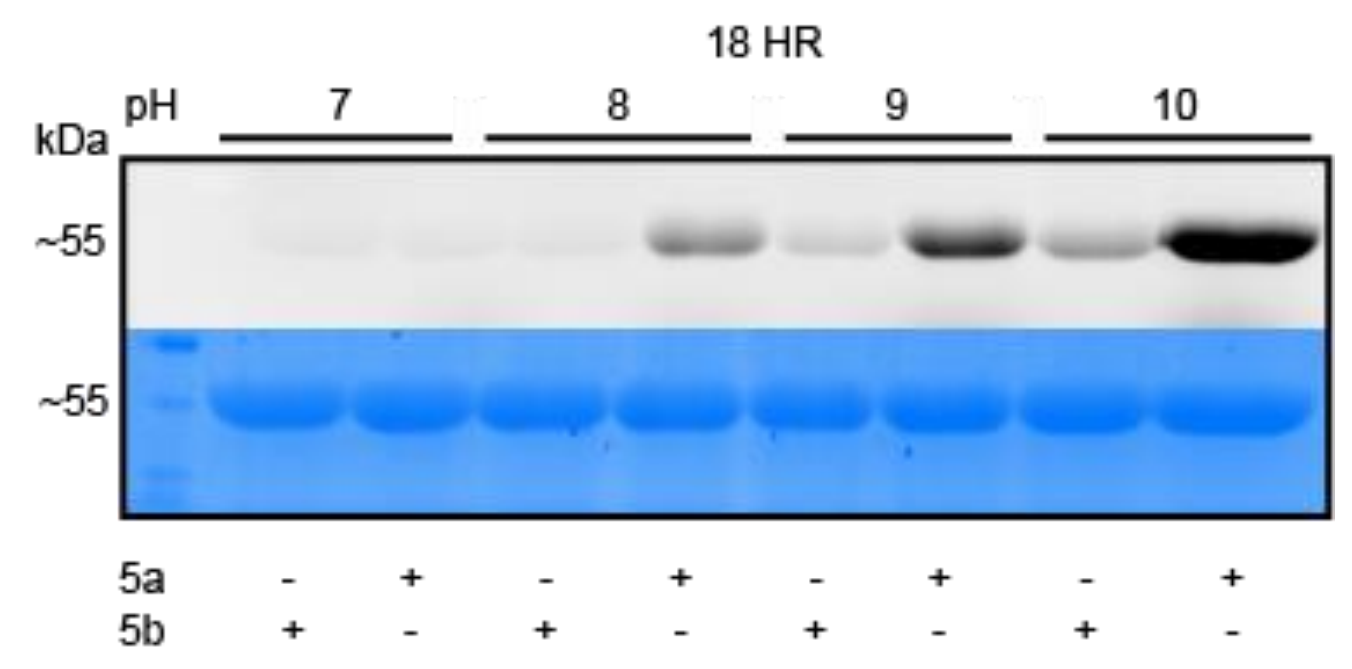

Figure S7. BSA labeled with $1 \mathrm{mM}$ compound $\mathbf{5 a}$ with increasing $\mathrm{pH}(7,8,9$ and 10) for 18 hours compared to BSA treated with $1 \mathrm{mM}$ of nonreactive $\mathbf{5 b}$. 
Gel electrophoresis of $\mathbf{5 a}$ and $\mathbf{5 b}$ treated samples -2 and 18 hour treatment

$20 \mu \mathrm{L}$ of each sample was mixed with $20 \mu \mathrm{L}$ of $2 X$ Laemmli sample buffer and vortexed. Samples were loaded on a $4 \%-12 \%$ SDS gel and fluorescence analyzed by electrophoresis using an Alexa 488 excitation laser line with Cy3 emission filter $(488 / 545 \mathrm{~nm})$. Quantification of band fluorescence was evaluated via ImageJ software.

\section{Quantification of BSA band fluorescence}

Quantification of band fluorescence was evaluated via ImageJ software. Band intensity was first measured for both the fluorescence image and the corresponding Coomassie image. Band intensity for each individual sample was quantified using band integration tools. Relative band concentration was normalized to the sample with the largest integration value, resulting in a respective ratio. Fluorescence integrations were then divided by respective intensity ratios of the Coomassie stain. Next, the fluorescence ratio of the experimental sample (Samples treated with either $\mathbf{4 a}$ or $\mathbf{5 a}$ ) was further normalized by subtracting the value from the respective control sample (Samples treated with $\mathbf{4 b}$ and $\mathbf{5 b}$ ) at each $\mathrm{pH}$. The final values for each $\mathrm{pH}$ were then normalized relative the sample with the highest fluorescence intensity ( $\mathrm{pH} 10$ sample) to provide a relative fluorescence value between 0 and 100, where 100 represents the fluorescence of the most fluorescent sample. Lastly, these relative fluorescent values were plotted on a bar chart relative to the $\mathrm{pH}$ of the sample.

Fluorescence evaluation of $4 \mathbf{a}$ and $\mathbf{4 b}$ gels -2 and 22 hour treatment

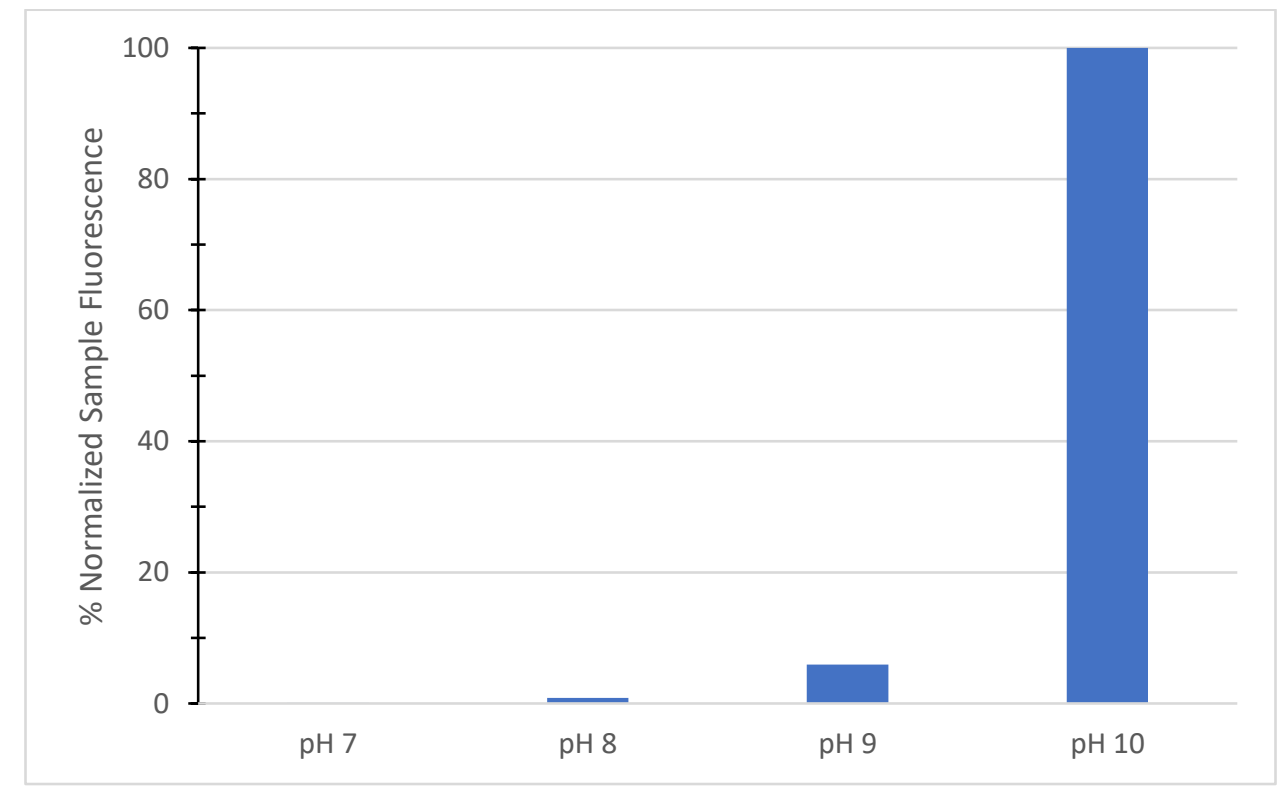

Figure S8. Fluorescence analysis of BSA labeled with $0.5 \mathrm{mM}$ compound $4 \mathrm{a}$ and $\mathrm{DBCO}$ at increasing $\mathrm{pH}(7,8,9$ and 10) for 2 hours. 


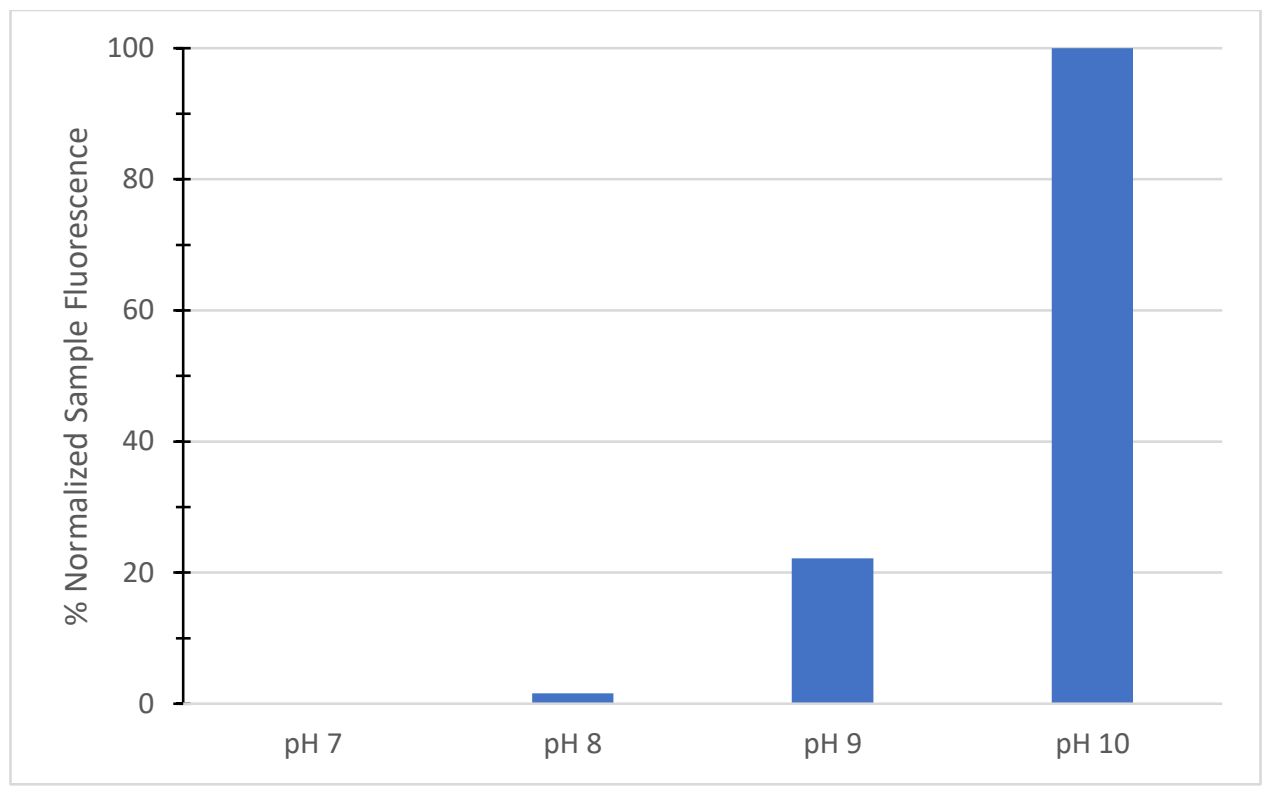

Figure S9. Fluorescence analysis of BSA labeled with $0.5 \mathrm{mM}$ compound $4 \mathrm{a}$ and Cy3 DBCO with increasing $\mathrm{pH}(7,8,9$ and 10$)$ for 22 hours.

Fluorescence evaluation of $5 \mathbf{a}$ gels -2 and 18 hour treatment

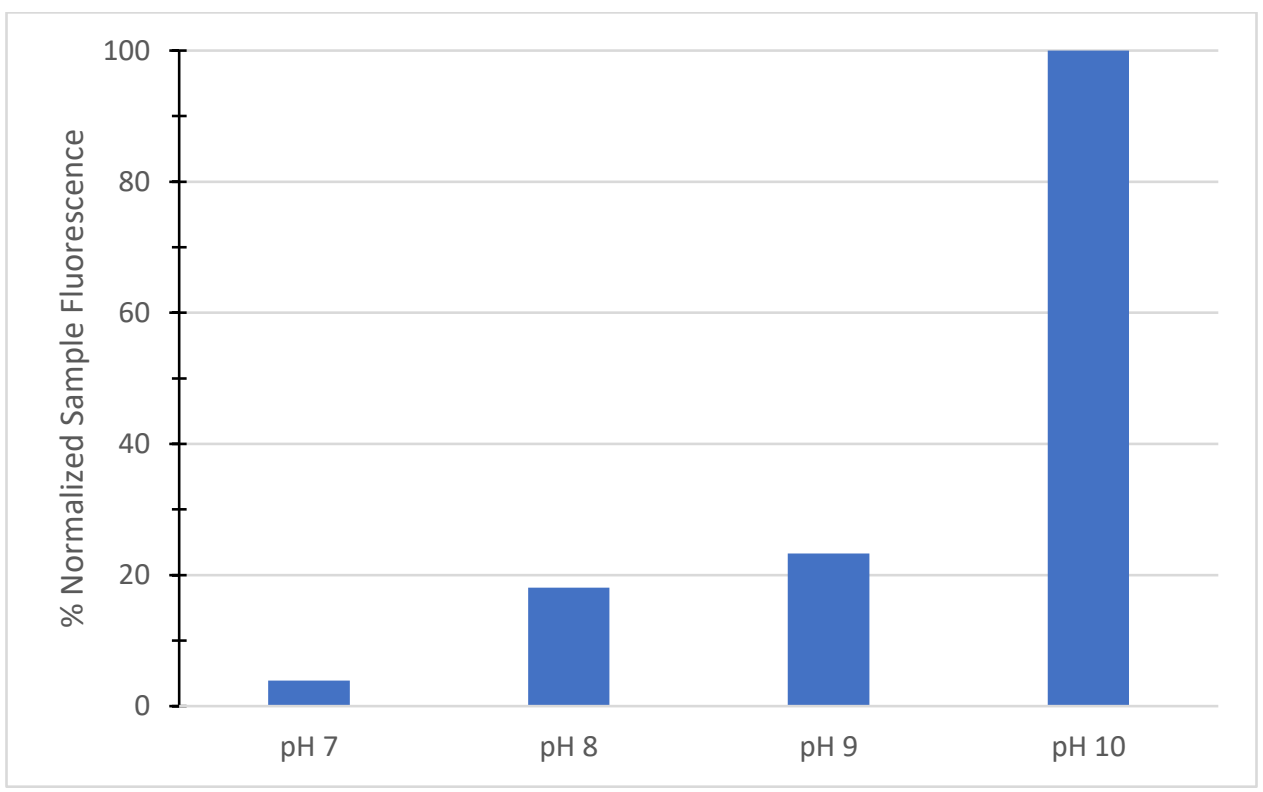

Figure S10. Fluorescence analysis of BSA labeled with $1 \mathrm{mM}$ compound 5a with increasing $\mathrm{pH}(7,8,9$ and 10) for 2 hours. 


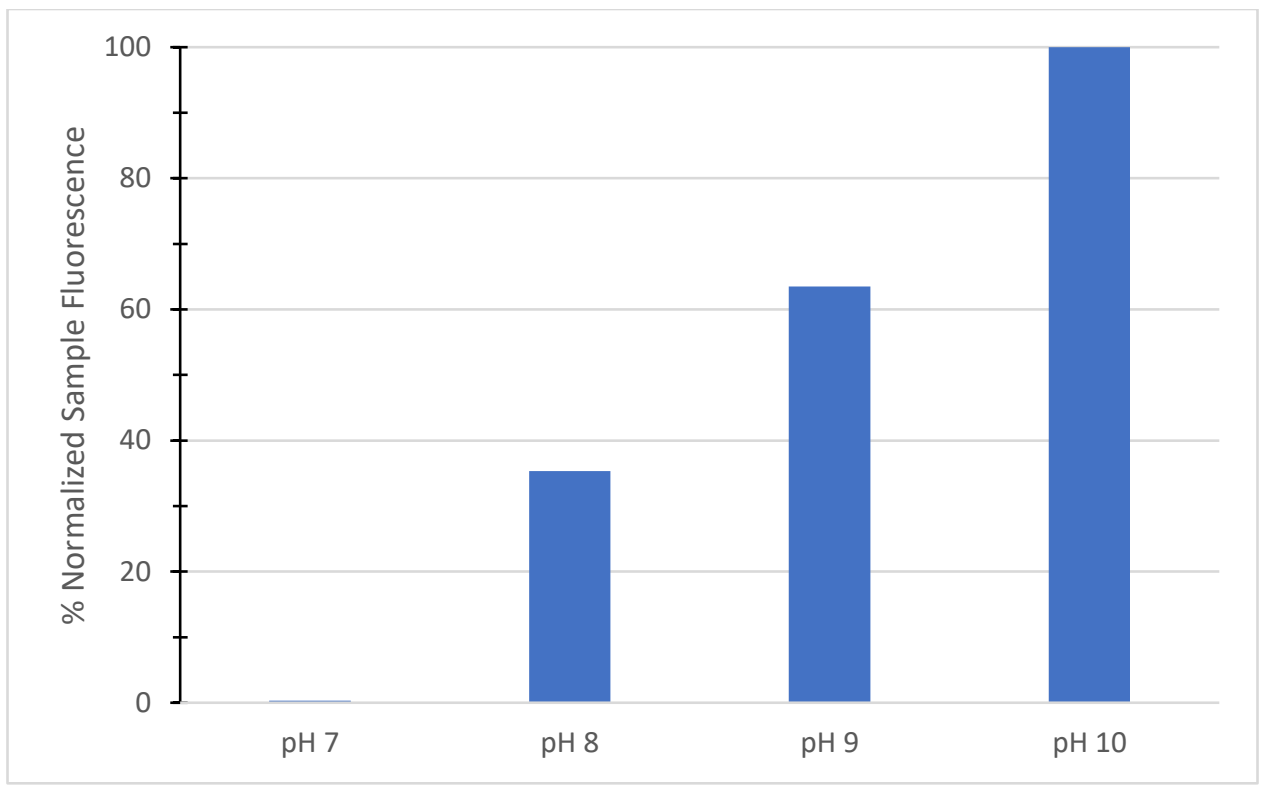

Figure S11. Fluorescence analysis of BSA labeled with $1 \mathrm{mM}$ compound 5a with increasing $\mathrm{pH}(7,8,9$ and 10$)$ for 18 hours. 


\section{Hydrolytic Studies}

\section{General Procedure}

Solutions of both 2 and 3 ( $15 \mathrm{mg}$ for each sample) were dissolved in 0.8 $\mathrm{mL}$ of 50:50 mixture of $\mathrm{D}_{2} \mathrm{O}$ and deuterated DMSO with a drop of acetonitrile. Sonication was used to aid in solvation. An initial NMR $(400 \mathrm{MHz})$ scan was taken and used as a reference. Corresponding samples were then treated with a drop of concentrated $\mathrm{HCl}$, or a small $\mathrm{NaOH}$ pellet to acidify and basify the samples, respectively. NMR timepoints were taken at the time indicated below. After the last scan, the basified samples were re-neutralized with $\mathrm{HCl}$ to $\mathrm{pH} 7$ and another NMR spectrum was collected immediately after.

Single Propyl MaMa (2)- High pH

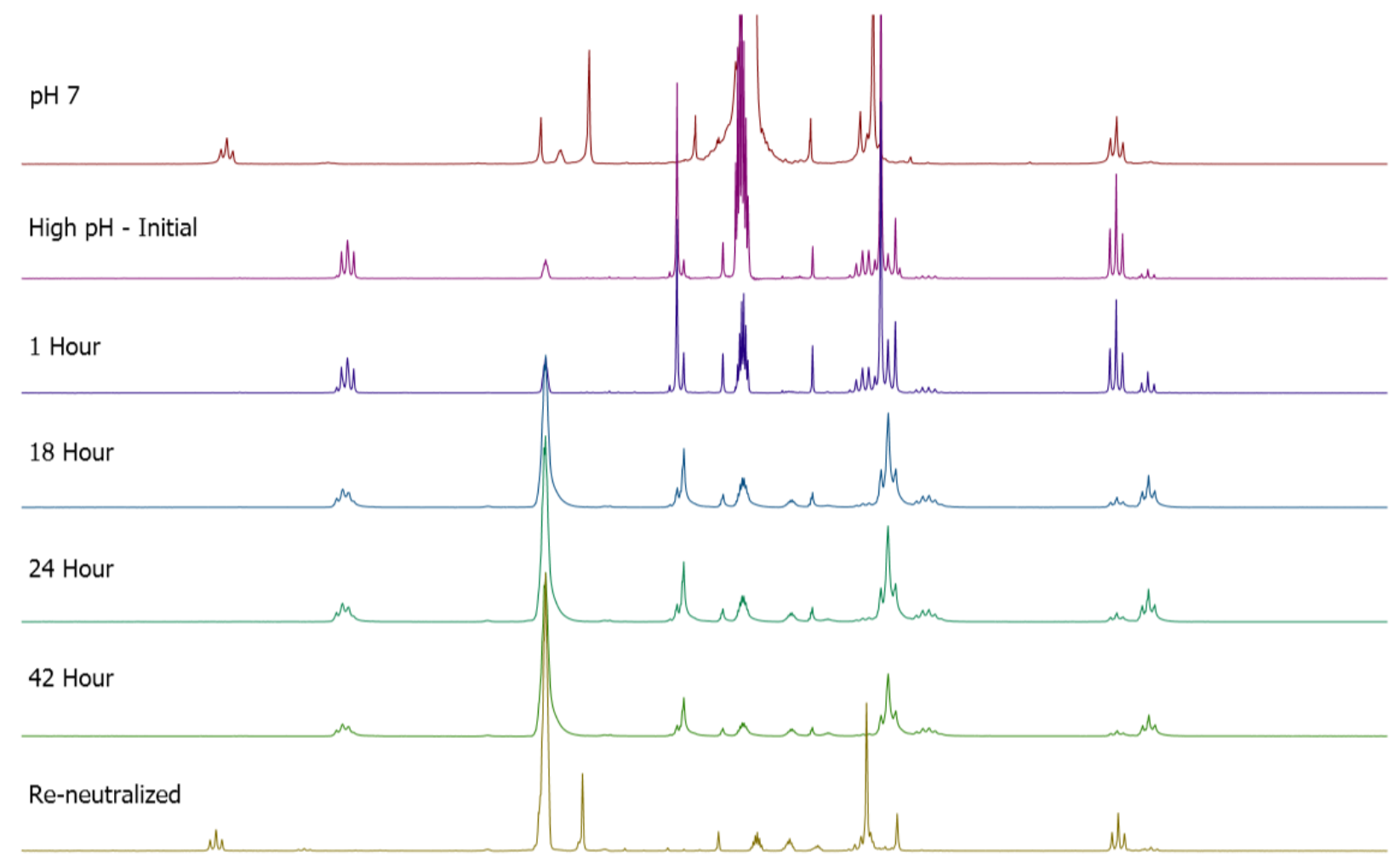

4.0 3.9 3.8 3.7 3.6 3.5 3.4 3.3 3.2 3.1 3.0 2.9 2.8 2.7 2.6 2.5 2.4 2.3 2.2 2.1 2.0 1.9 1.8 1.7 1.6 1.5 1.4 1.3 1.2 1.1 1.0 0.9 0.8 0.7 0.6 0.5 0.4 0.3 0.2 0.1

Figure S12: Hydrolytic NMR study of 2 at high $\mathrm{pH}$. Top NMR was taken immediately after dissolving in $\mathrm{D}_{2} \mathrm{O}$. Once basified, an initial NMR was taken and then at referenced hours after. After 42 hours, the sample was re-neutralized to $\mathrm{pH}$ 7 and an NMR was quickly taken after. The spectrum showed reversion back to the initial $\mathrm{pH} 7$ peaks, showing a quick, reversible modification. 


\section{Single Propyl MaMa (2) - Neutral pH}

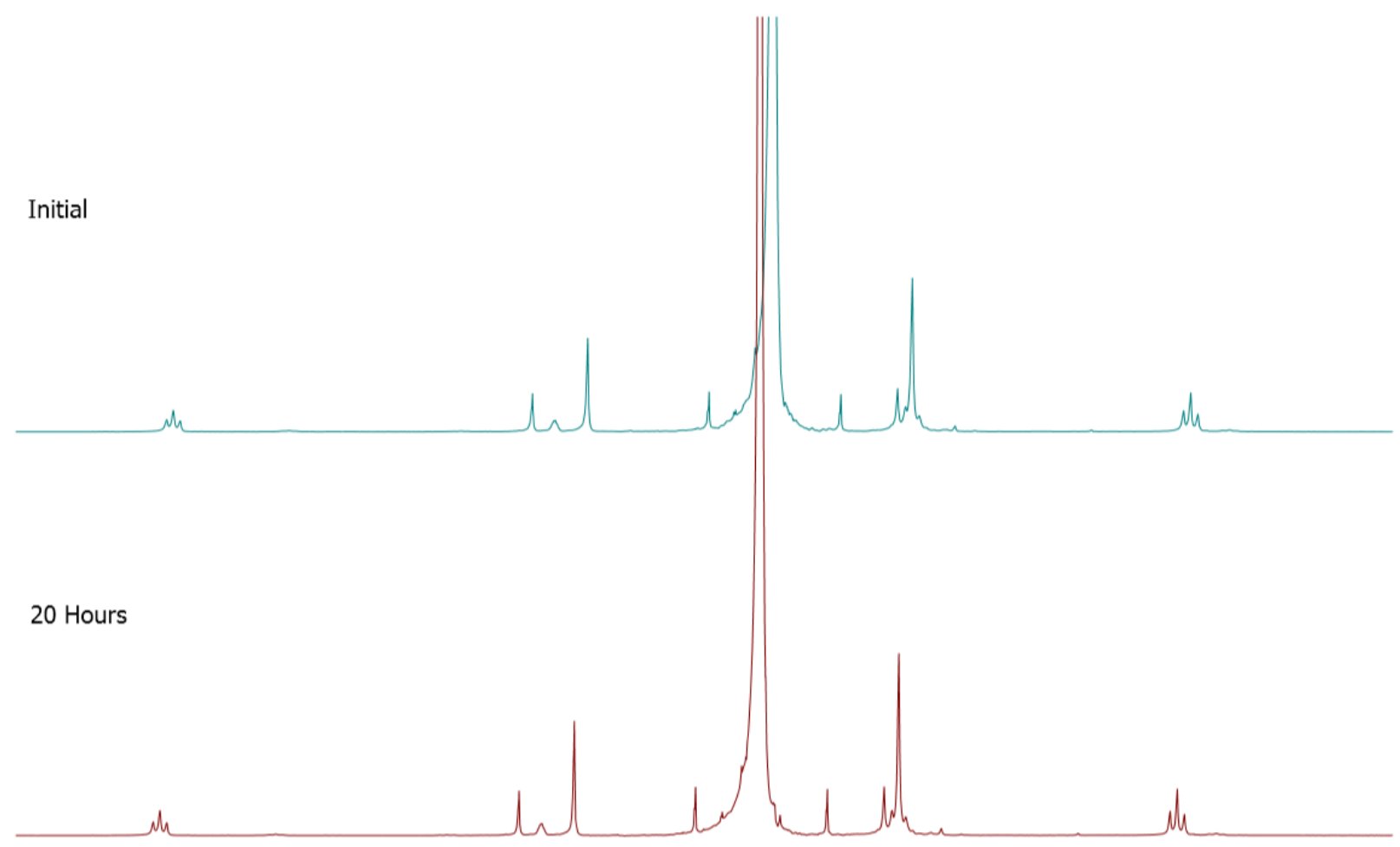

$\begin{array}{llllllllllllllllllllllllllllllllllllllllllllll}3.8 & 3.7 & 3.6 & 3.5 & 3.4 & 3.3 & 3.2 & 3.1 & 3.0 & 2.9 & 2.8 & 2.7 & 2.6 & 2.5 & 2.4 & 2.3 & 2.2 & 2.1 & 2.0 & 1.9 & 1.8 & 1.7 & 1.6 & 1.5 & 1.4 & 1.3 & 1.2 & 1.1 & 1.0 & 0.9 & 0.8 & 0.7 & 0.6 & 0.5 & 0.4 & 0 .\end{array}$

Figure S13: Hydrolytic NMR study of 2 at neutral $\mathrm{pH}$. Top NMR was taken immediately after dissolving in $\mathrm{D}_{2} \mathrm{O}$. Bottom NMR was taken 20 hours later and showed no shift or change in peaks, illustrating stability at neutral $\mathrm{pH}$. 
Double Propyl MaMa (3) - High pH

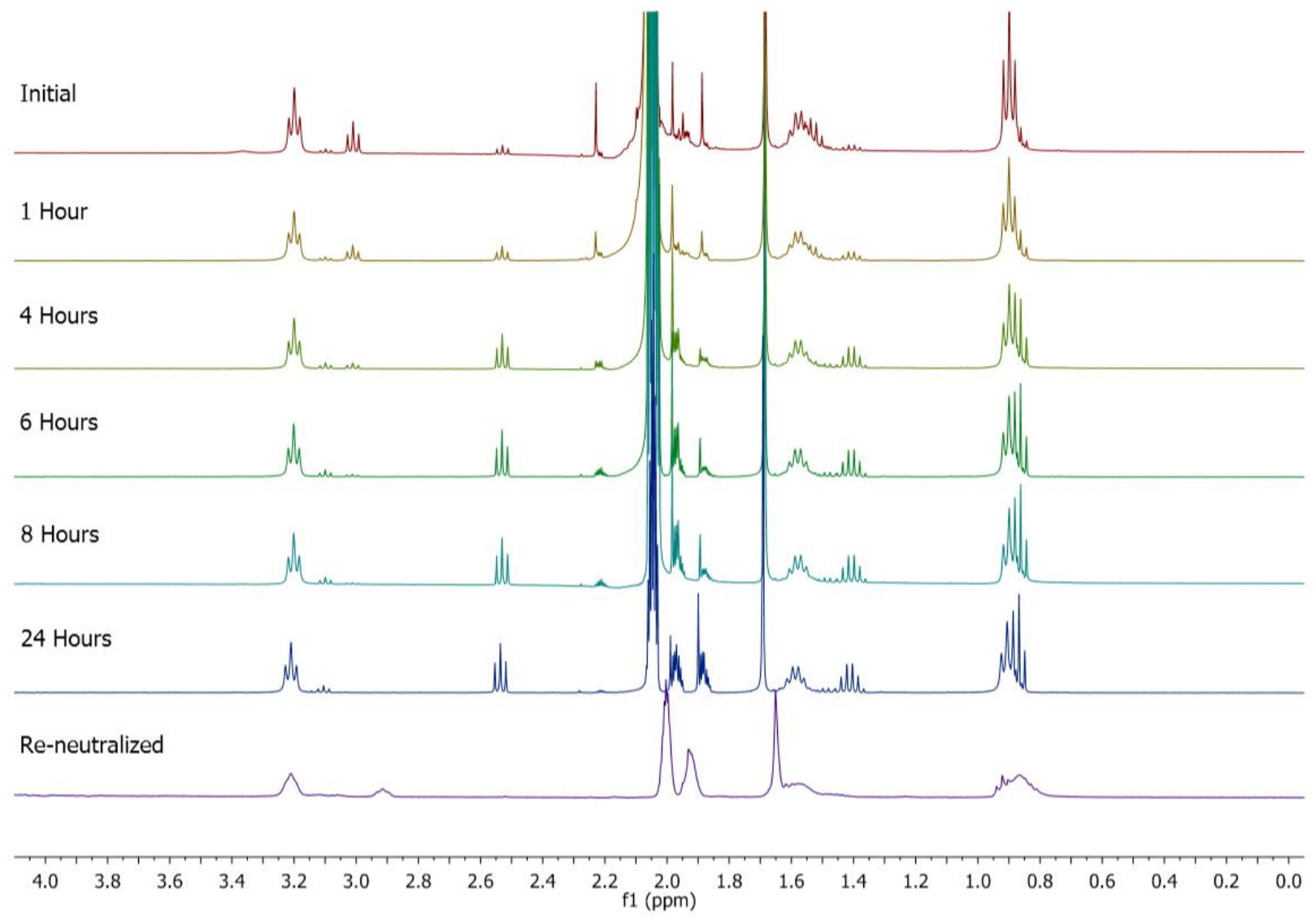

Figure S14: Hydrolytic NMR study of 3 at high $\mathrm{pH}$. Top NMR was taken immediately after dissolving in basic $\mathrm{D}_{2} \mathrm{O}$. An NMR was taken at referenced hours after. After 24 hours, the sample was re-neutralized to $\mathrm{pH} 7$, with peaks reverting back to original, initial shifts, showing reversible modification. 
Double Propyl MaMa (3) - Neutral pH

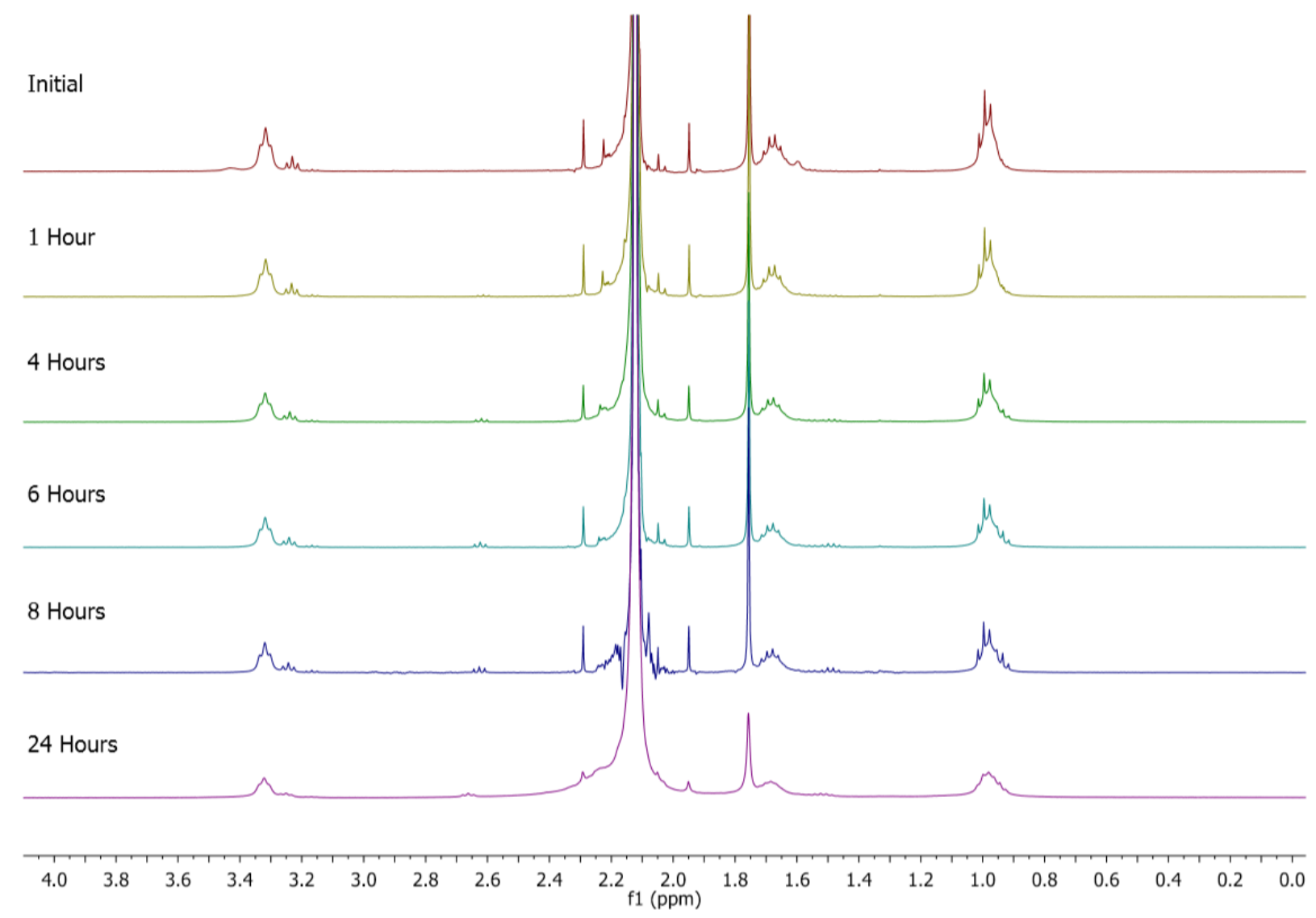

Figure S15: Hydrolytic NMR study of 3 at neutral $\mathrm{pH}$. Top NMR was taken immediately after dissolving in $\mathrm{D}_{2} \mathrm{O}$. An NMR was taken at referenced hours after. After 24 hours, the sample showed no change in peaks or shifts, showing stability at low $\mathrm{pH}$. 
Double Propyl MaMa (3) - Low pH

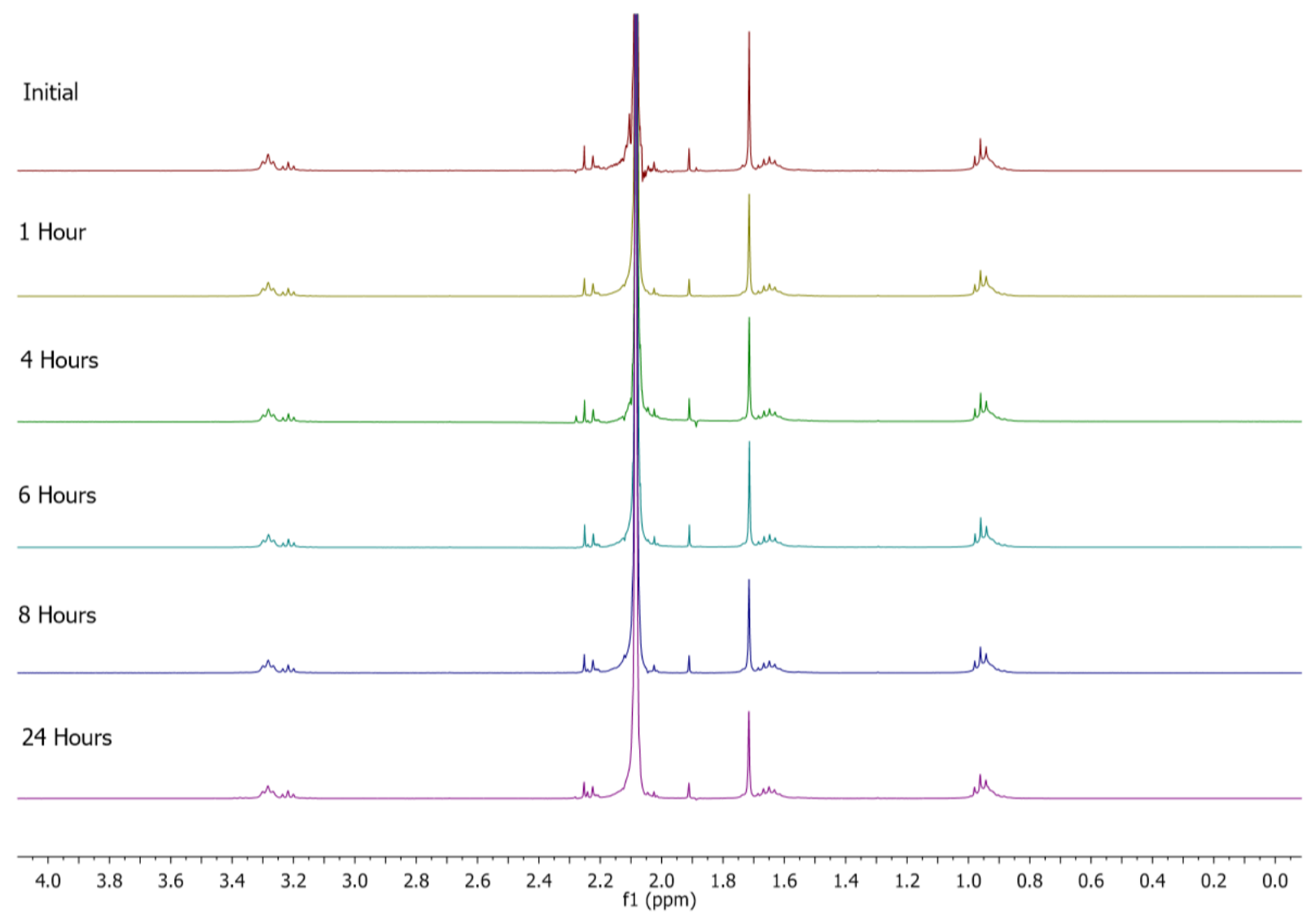

Figure S16: Hydrolytic NMR study of 3 at low $\mathrm{pH}$. Top NMR was taken immediately after dissolving in acidic $\mathrm{D}_{2} \mathrm{O}$. An NMR was taken at referenced hours after. After 24 hours, the sample showed no change in peaks or shifts, showing stability at low $\mathrm{pH}$. 


\section{Chemical Stability Studies}

\section{General Procedure}

Stability of 3 in presence of various nucleophiles at $\mathrm{pH} 7$ and $\mathrm{pH} 10$

1) Treatment with Cysteine

$20 \mathrm{mg}(0.074 \mathrm{mmol})$ of $3(270.33 \mathrm{~g} / \mathrm{mol})$ was dissolved in $1 \mathrm{~mL}$ of acetonitrile and added to a $5 \mathrm{~mL}$ solution of $0.5 \mathrm{M}$ PBS buffer $\mathrm{pH} 7(16.7 \% \mathrm{ACN})$ containing $\sim 1$ equivalent (12 $\mathrm{mg}, 0.076 \mathrm{mmol})$ of cysteine $\mathrm{HCl}(157.62 \mathrm{~g} / \mathrm{mol})$. The resulting reaction was magnetically stirred overnight for a total of 24 hours and then the reaction solution was evaporated by air stream. Reaction products were extracted with $\mathrm{MeOH}$ and pumped down by vacuum. The resulting solid was then dissolved in deuterated DMSO and analyzed by ${ }^{1} \mathrm{H}$ NMR to determine spectral differences compared to pure 3 . This experiment was repeated using $0.2 \mathrm{M}$ Borate buffer $\mathrm{pH} 10$.

\section{2) Treatment with DTT}

$20 \mathrm{mg}(0.074 \mathrm{~mol})$ of 3 was dissolved in $1 \mathrm{~mL}$ of acetonitrile and added to a $5 \mathrm{~mL}$ solution of $0.5 \mathrm{M}$ PBS buffer $\mathrm{pH} 7$ containing $\sim$ equivalent $(12 \mathrm{mg}, 0.078 \mathrm{mmol}$ ) of DTT $(154.25 \mathrm{~g} / \mathrm{mol})$. The resulting reaction was magnetically stirred overnight for a total of 24 hours and then the reaction solution was evaporated by air stream. Reaction products were extracted with $\mathrm{MeOH}$ and pumped down by vacuum. The resulting solid was then dissolved in deuterated DMSO and analyzed by ${ }^{1} \mathrm{H}$ NMR to determine spectral differences compared to pure 3 . This experiment was repeated using $0.2 \mathrm{M}$ Borate buffer $\mathrm{pH} 10$. 
Double Propyl MaMa (3) - $\mathrm{pH} 7$

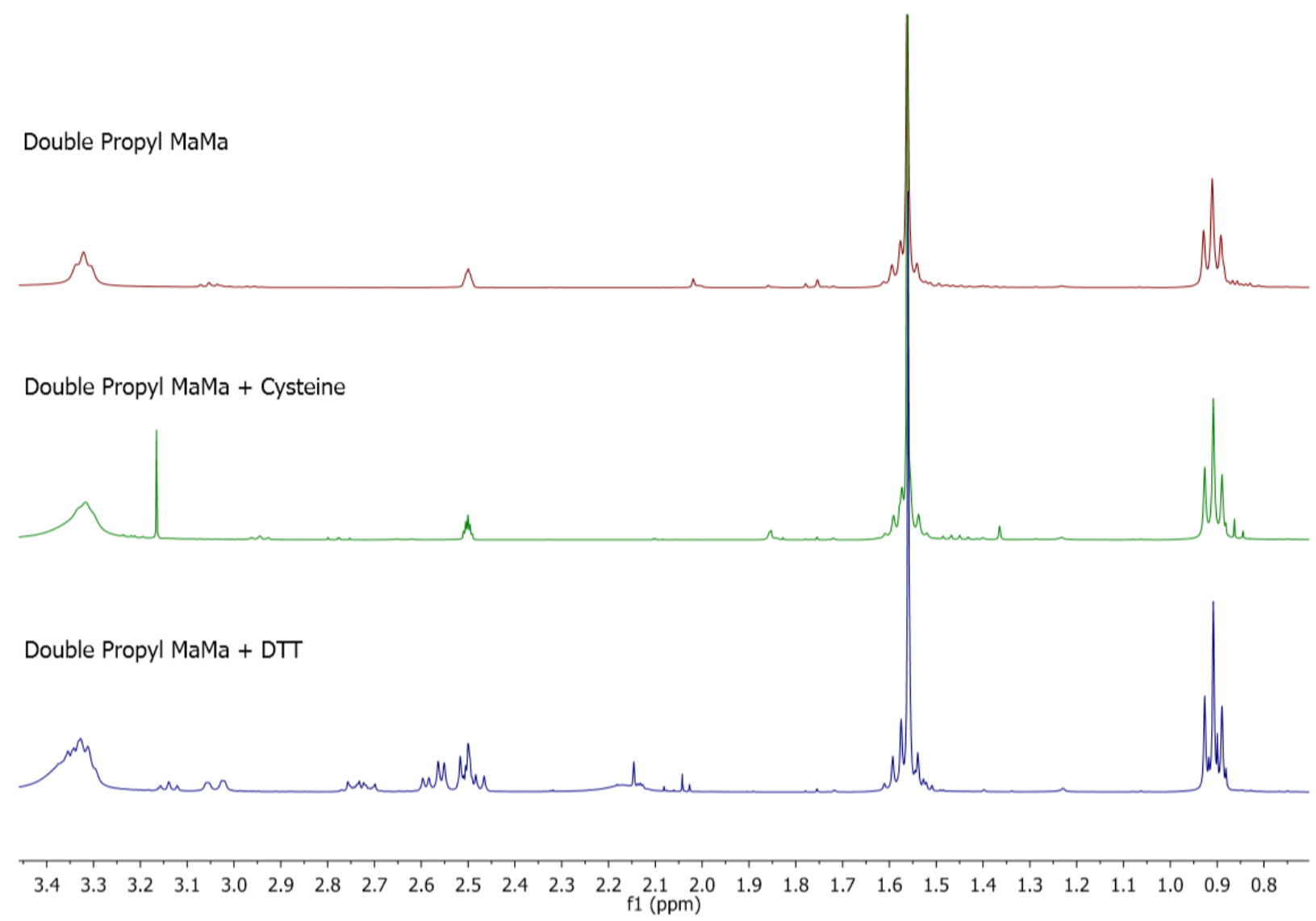

Figure S17: Chemical stability of 3 against cysteine and DTT at pH 7. Top NMR shows $\mathbf{3}$ in DMSO alone. Middle and bottom NMR shows products of $\mathbf{3}$ treated with cysteine and DTT, respectively. Peaks for initial 3 are present in both cases, showing stability against DTT and cysteine. 
Double Propyl MaMa (3) - pH 10

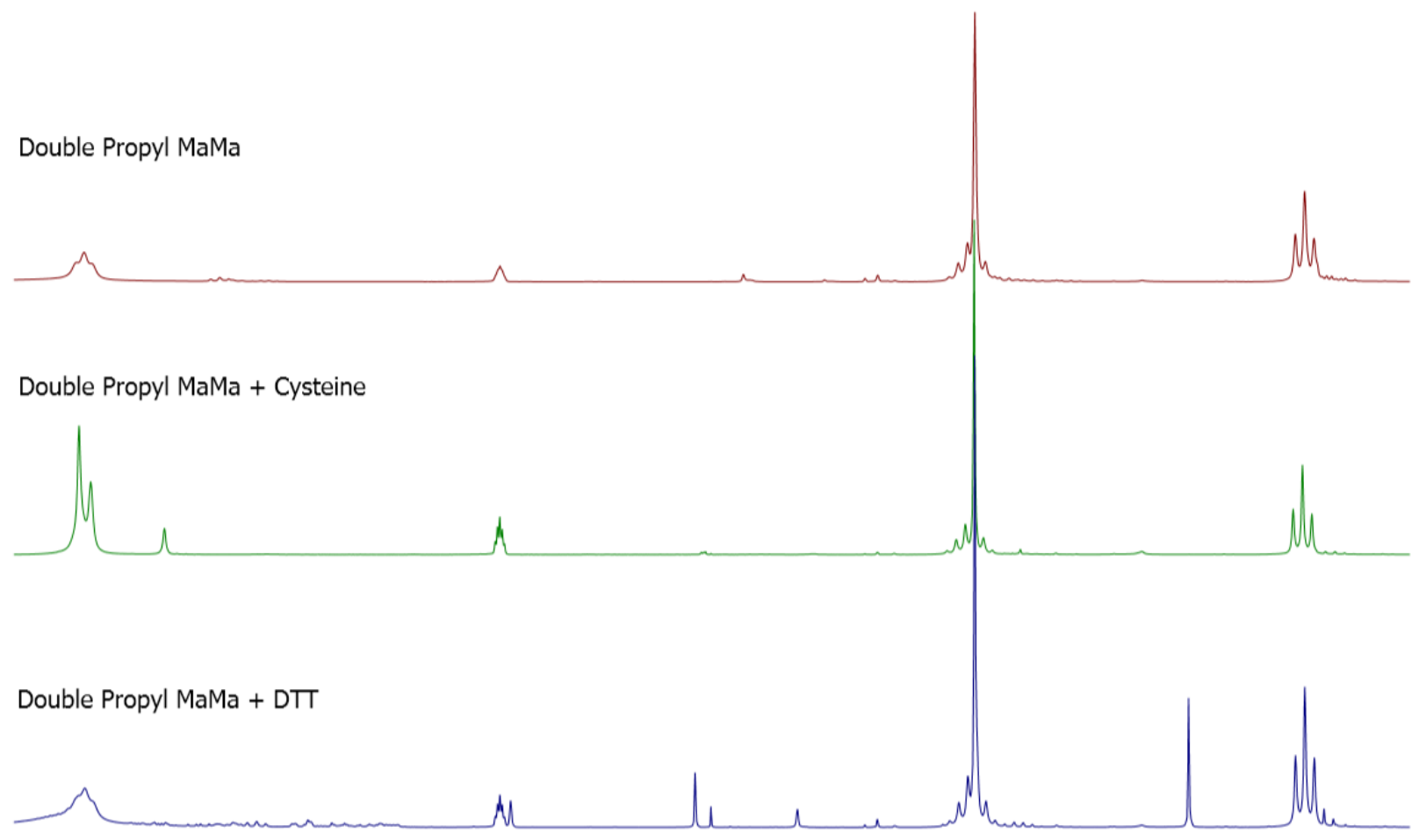

$\begin{array}{lllllllllllllllllllllllllll}3.4 & 3.3 & 3.2 & 3.1 & 3.0 & 2.9 & 2.8 & 2.7 & 2.6 & 2.5 & 2.4 & 2.3 & 2.2 & 2.1 & 2.0 & 1.9 & 1.8 & 1.7 & 1.6 & 1.5 & 1.4 & 1.3 & 1.2 & 1.1 & 1.0 & 0.9 & 0.8\end{array}$

Figure S18: Chemical stability of 3 against cysteine and DTT at $\mathrm{pH}$ 10. Top NMR shows $\mathbf{3}$ in DMSO alone. Middle and bottom NMR shows products of $\mathbf{3}$ with cysteine and DTT, respectively. Peaks for initial $\mathbf{3}$ are present in both cases, showing stability against DTT and cysteine. 


\section{Amine/Thiol Competition Studies}

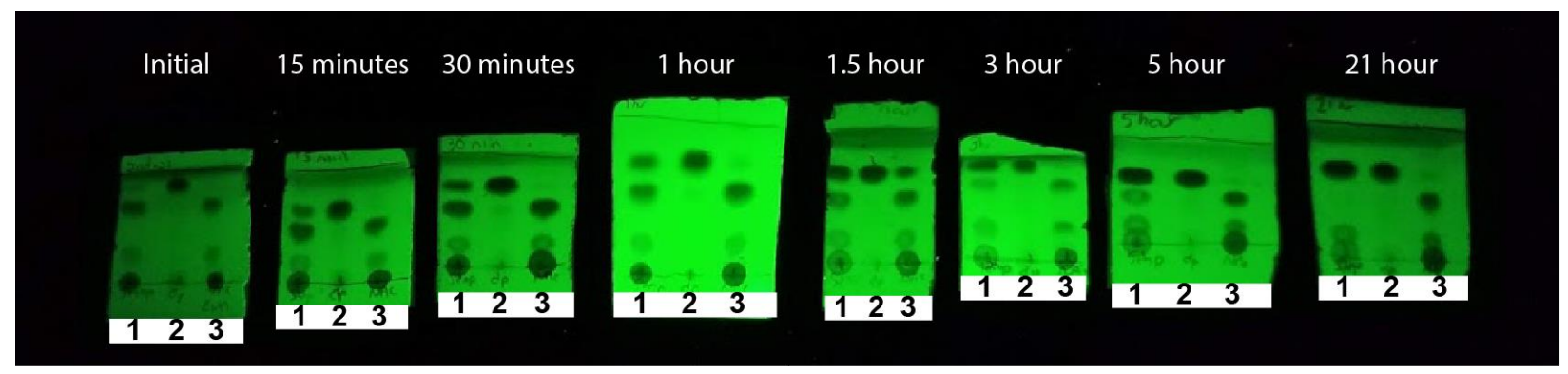

Figure S19: Thiol/amine addition competition to 2.2 (0.008 g, $0.031 \mathrm{mmoles})$ was added to a solution of $\mathrm{N}$-acetylated cysteine $(0.010 \mathrm{~g}, 0.062 \mathrm{mmoles})$ and propyl amine (0.005 mL, 0.062 mmoles) in $0.6 \mathrm{~mL}$ of $5: 1 \mathrm{pH} 10$ sodium borate buffer:MeCN. Reaction was stirred at room temperature and monitored for product formation via TLC in 1:1 hexanes:ethyl acetate at noted times. Lane 1 is the reaction sample, lane 2 is $\mathbf{3}$, and lane $\mathbf{3}$ is a mixture of $\mathbf{S 4}$ (baseline) and $\mathbf{1}$ (higher Rf). Overtime, $\mathbf{3}$ shows to be the predominate product. The signal remaining at the baseline is suspected to be primarily free $\mathrm{N}$-acetylated cysteine. This spot appears to be diminishing overtime, illustrating if any $\mathrm{N}$-acetylated MaMa adduct formed, it is reverting into the double propyl adduct (3). 


\section{Absorbance Spectra}

\section{General}

$1 \mathrm{mg} / \mathrm{mL}$ stocks were made by dissolving $1 \mathrm{mg}$ of respective compounds 2 and 3 into 1 $\mathrm{mL}$ of DMSO. From that stock, $10 \mu \mathrm{L}$ was added to $990 \mu \mathrm{L}$ of either $0.1 \mathrm{M} \mathrm{PBS} \mathrm{pH} 7$ or $0.1 \mathrm{M}$ of Borate buffer $\mathrm{pH} 10$. Resulting solutions were scanned using an Agilent 8453 UV/Vis spectroscopy system under kinetics mode.

Absorbance spectra for single propyl MaMa (2) at $\mathrm{pH} 7$ and 10
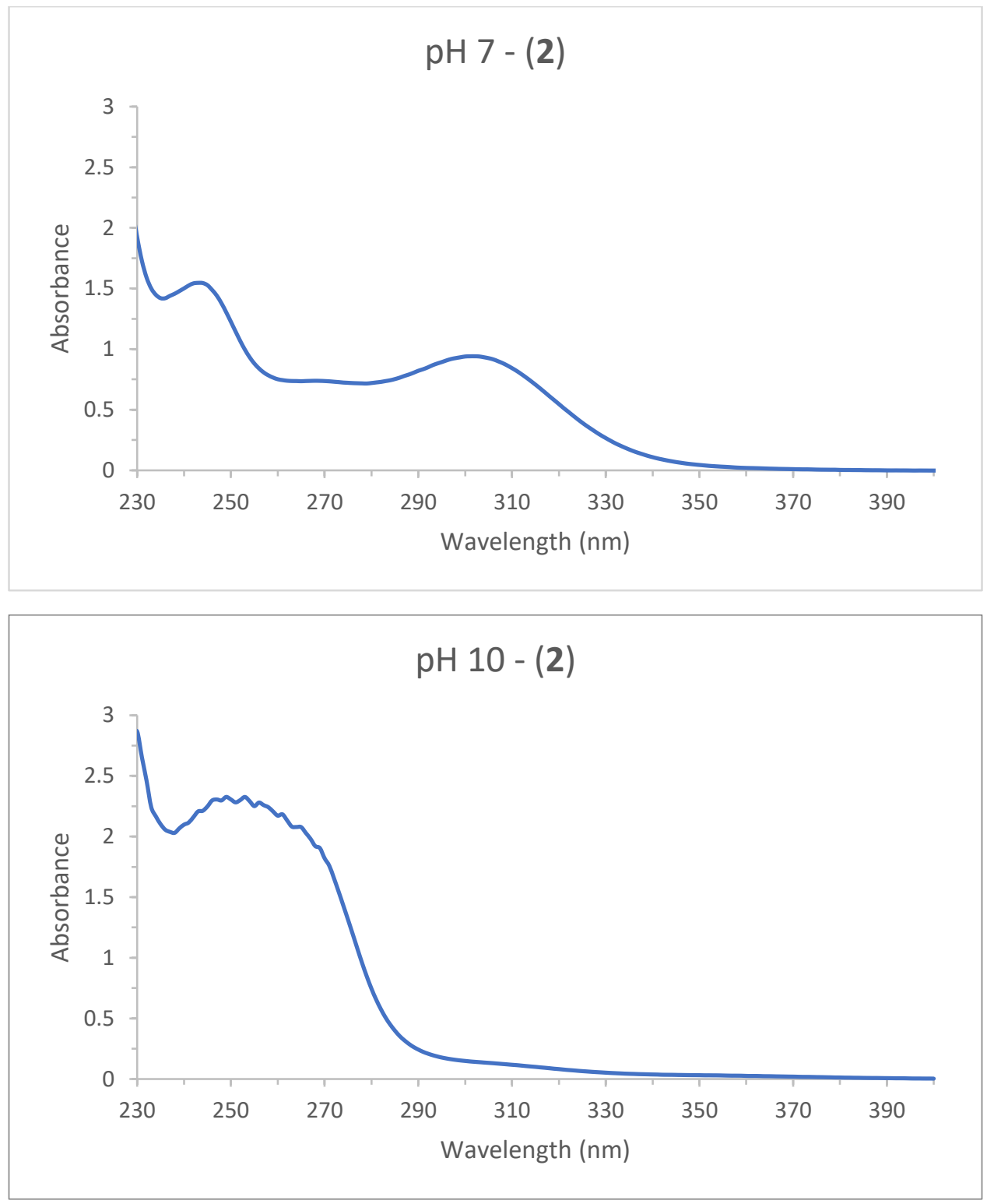
Absorbance spectra for double propyl MaMa (3) at pH 7 and 10
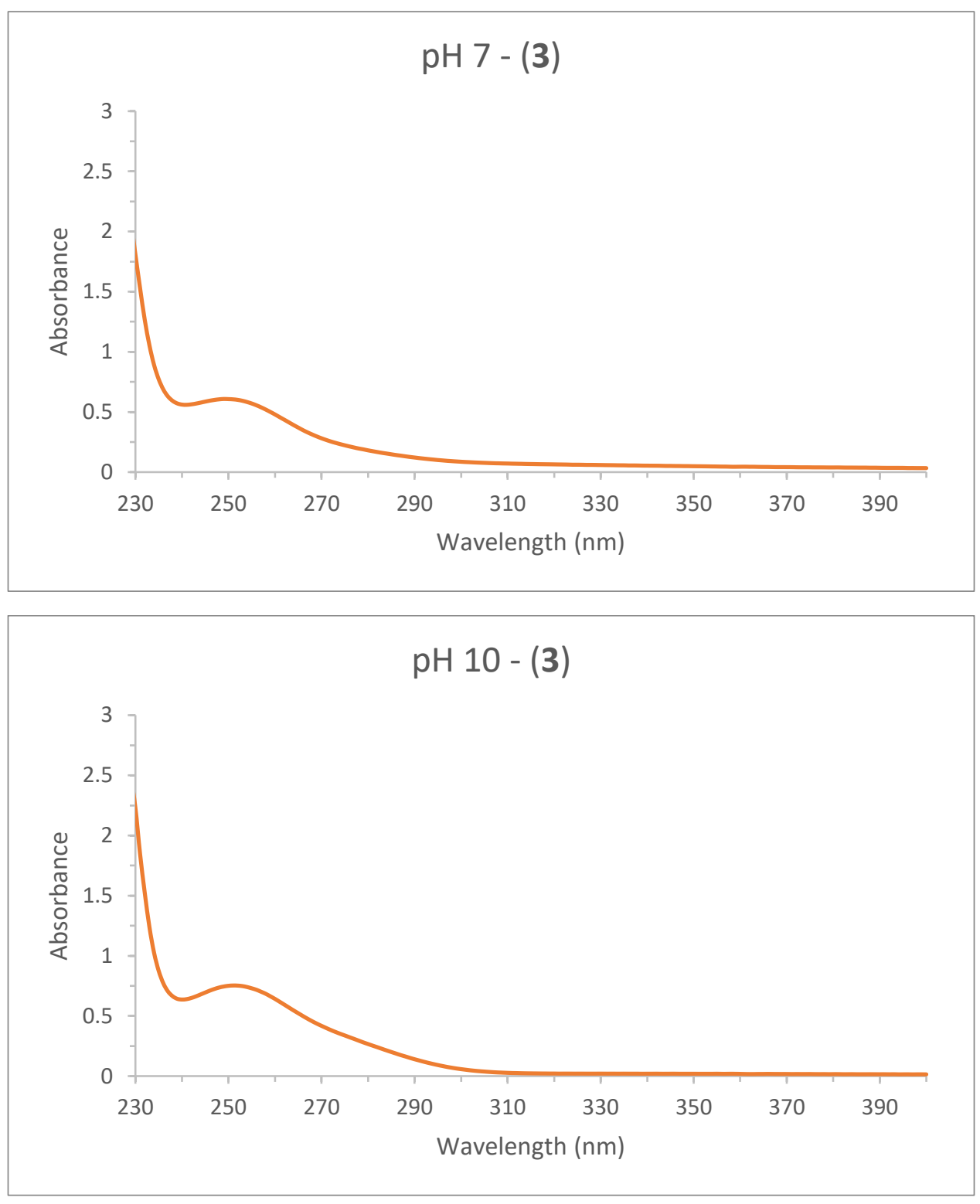


\section{References}

(1) Cheikh, A. Ben; Chuche, J.; Manisse, N.; Pommelet, J. C.; Netsch, K. P.; Lorencak, P.; Wentrup, C. Synthesis of a-Cyano Carbonyl Compounds by Flash Vacuum Thermolysis of (Alkylamino)Methylene Derivatives of Meldrum's Acid. Evidence for Facile 1,3-Shifts of Alkylamino and Alkylthio Groups in Imidoylketene Intermediates. J. Org. Chem. 1991, 56 (3), 970-975. https://doi.org/10.1021/jo00003a014.

(2) Montero, A.; Goya, P.; Jagerovic, N.; Callado, L. F.; Meana, J. J.; Girón, R.; Goicoechea, C.; Martín, M. I. Guanidinium and Aminoimidazolinium Derivatives of $\mathrm{N}$-(4-Piperidyl)Propanamides as Potential Ligands for $\mu$ Opioid and I2-Imidazoline Receptors: Synthesis and Pharmacological Screening. Bioorganic Med. Chem. 2002, 10 (4), 1009-1018. https://doi.org/10.1016/S0968-0896(01)00356-X.

(3) Renslo, A.; Mahajan, S. Prodrug Compositions and Methods for Using the Same in Treating Cancer and Malaria, 2009.

(4) Wessjohann, L. A.; Morejón, M. C. M.; Ojeda, G. M.; Rhoden, C. R. B.; Rivera, D. G. Applications of Convertible Isonitriles in the Ligation and Macrocyclization of Multicomponent Reaction-Derived Peptides and Depsipeptides. 2016. https://doi.org/10.1021/acs.joc.6b01150.

(5) Mello-Vieira, J.; Sousa, T.; Coutinho, A.; Fedorov, A.; Lucas, S. D.; Moreira, R.; Castro, R. E.; Rodrigues, C. M. P.; Prieto, M.; Fernandes, F. Cytotoxic Bile Acids, but Not Cytoprotective Species, Inhibit the Ordering Effect of Cholesterol in Model Membranes at Physiologically Active Concentrations. Biochim. Biophys. Acta Biomembr. 2013, 1828 (9), 2152-2163.

https://doi.org/10.1016/j.bbamem.2013.05.021. 


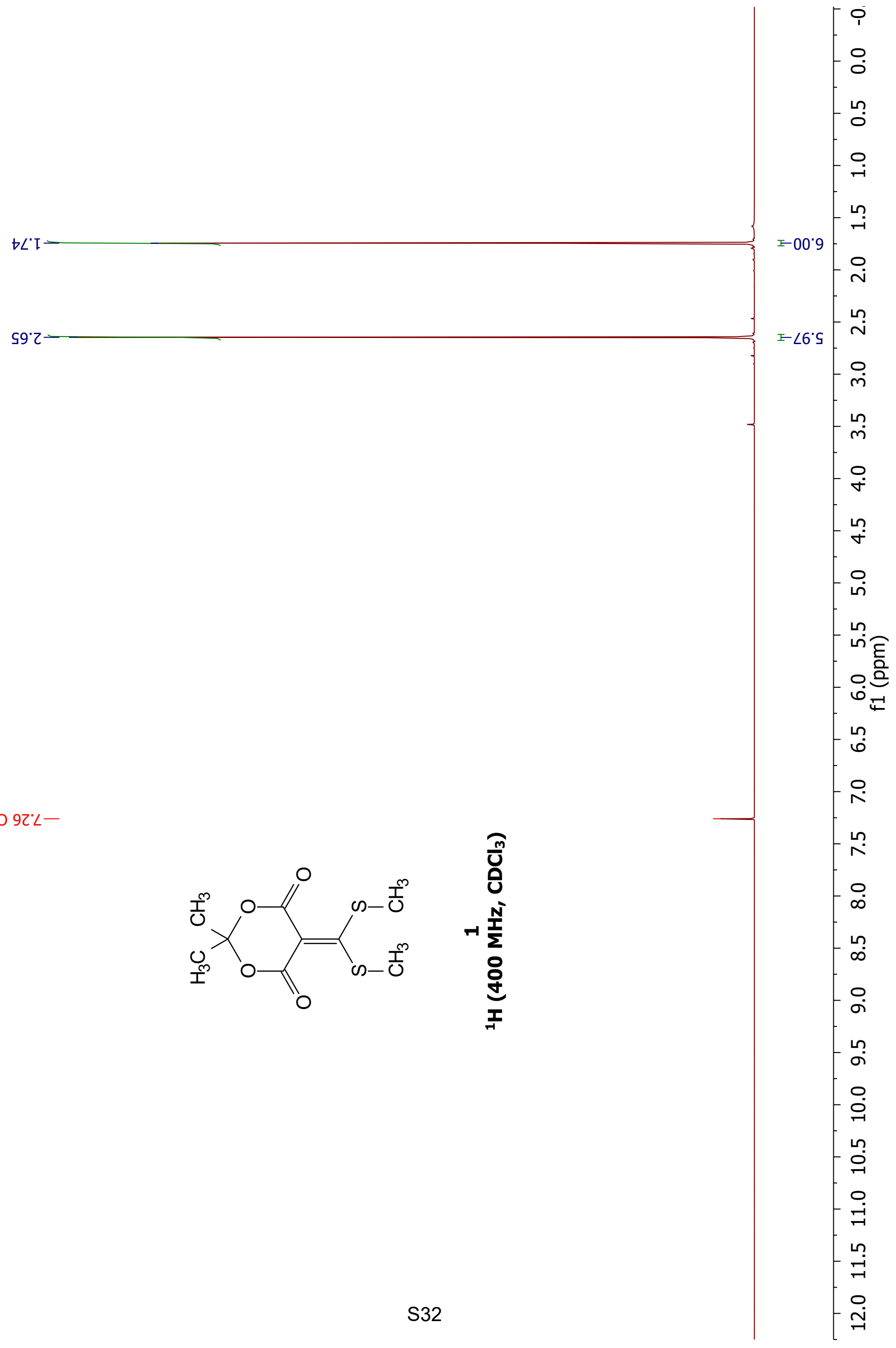




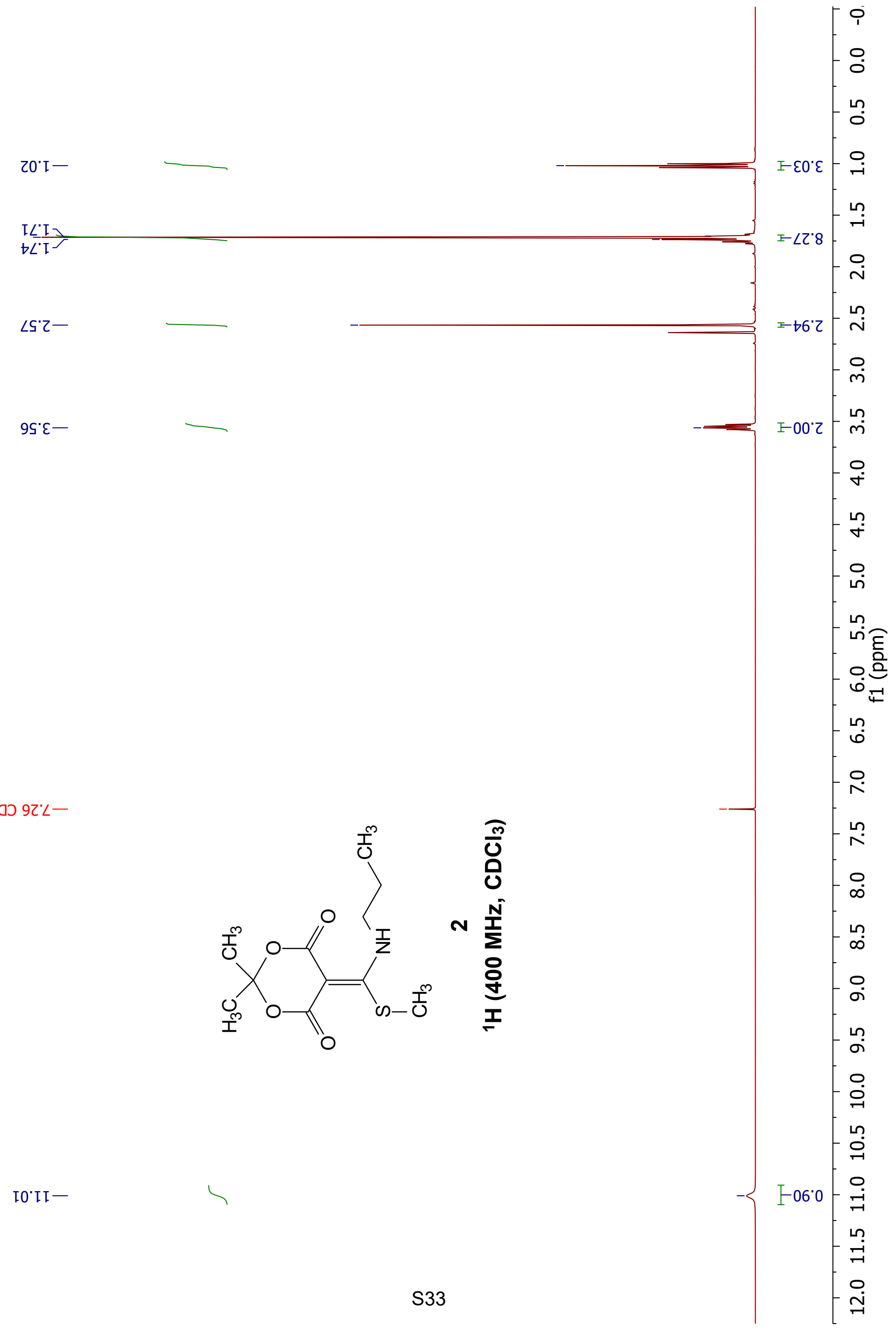


IE'II-

SE' $8 \mathrm{I}$

$\angle b^{\circ} I Z 工$

SI.92 -

$\varepsilon 8^{\circ} 9 \tau^{-}$

โ ${ }^{\circ} \angle t-$

ع|गه $\varepsilon \angle ' 9 L$

हIJOJ S0'LL-

हागव $9 \varepsilon^{\prime \prime} \angle L$

$00^{\circ} \varepsilon 8^{-}$

$\angle 9^{\circ} \mathrm{ZOI}-$

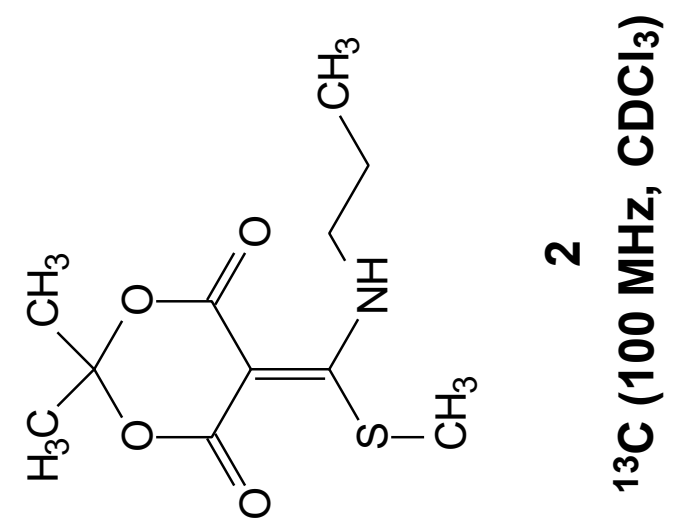

๑6 $ะ 9$ I -

$89^{\circ} 8 \angle I-$ 
S9:

$\angle \varepsilon^{\prime} \varepsilon-$

ع|ग๐ 92'L-

ع8.6-

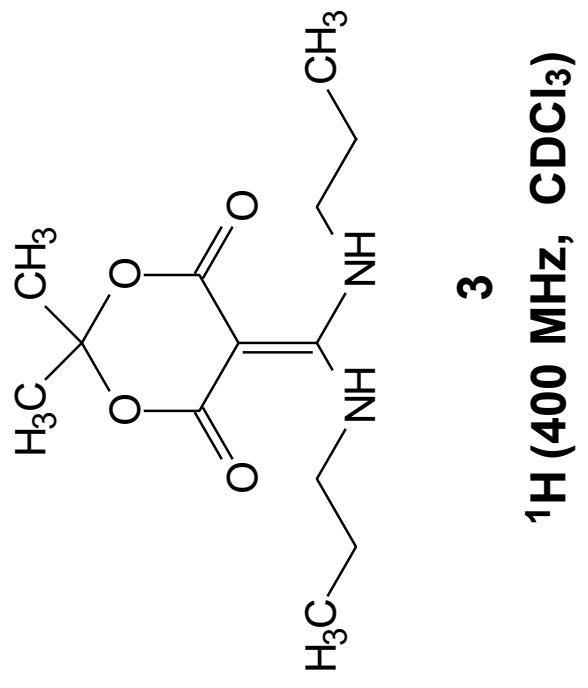


00'20I-

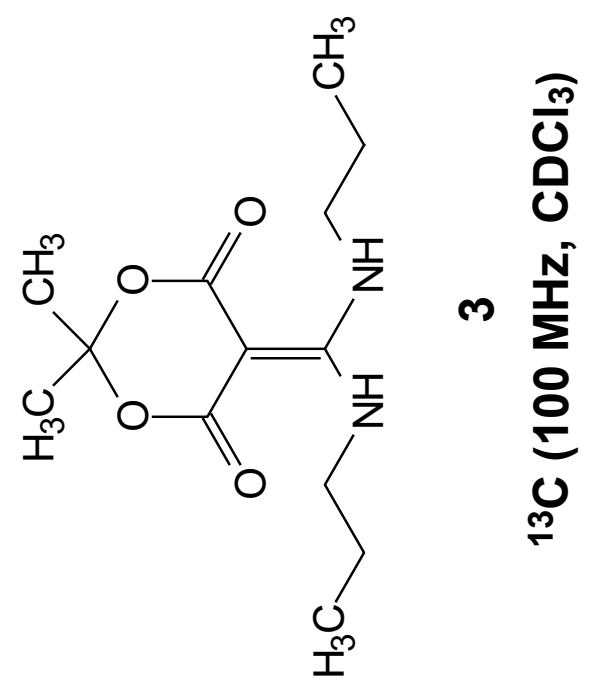




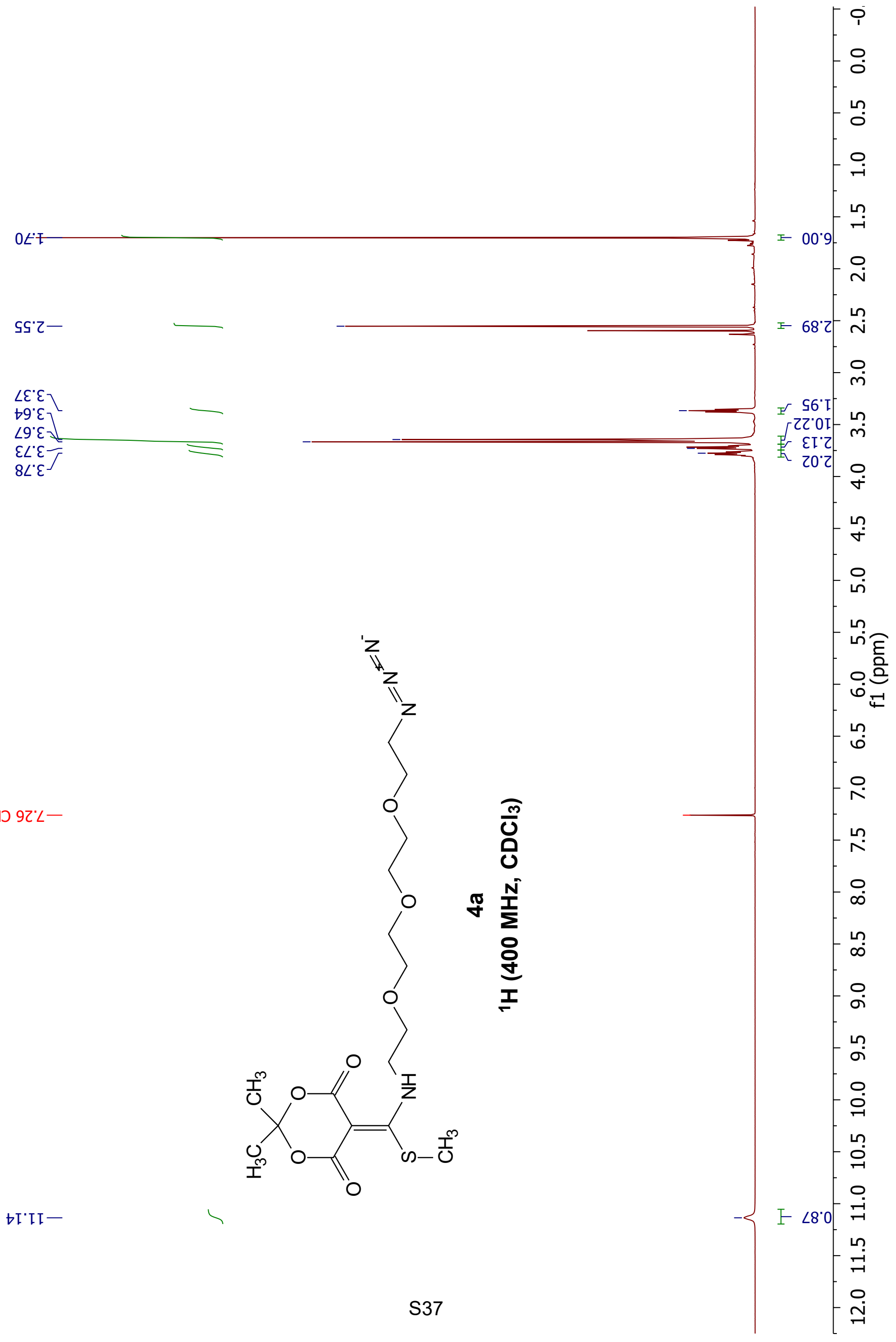


$0 t^{\circ} 8 \mathrm{I}-$

$6 I^{\circ} 97-$

$86^{\circ} 0 t^{\circ}$

26.St-

99.0S \

$29^{\circ} 89$

$86^{\circ} 69$

$\varepsilon 9^{\circ} 0<$

$59^{\circ} 0<$ ]

$89^{\circ} 0<>$

$\varepsilon 8^{\circ} 0 \angle$

हागه $\mathrm{s} \angle$ ' $9 \angle>$

हाग) $\angle 0^{\circ} \angle L J$

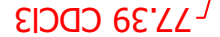

โt' $\varepsilon 8$

เ9'20I-

8L'๕9I-

$59^{\circ} 8 \angle I-$

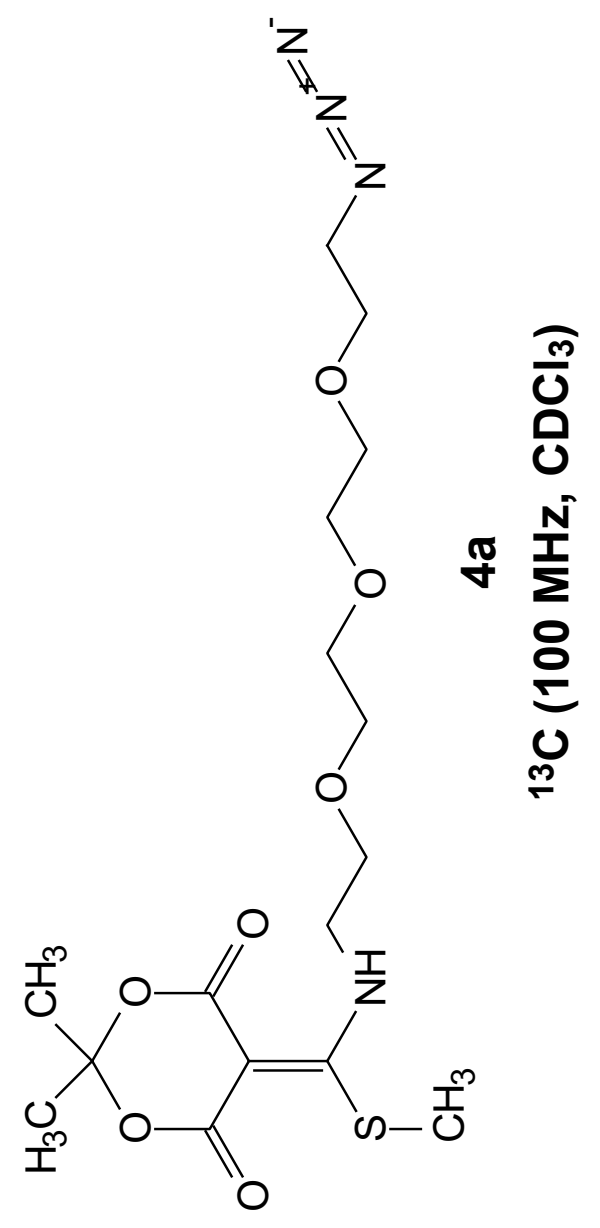


$86^{\circ} 0-$

ह9. $I$ ᄀ

ธะ' $\varepsilon-$

$\left.85^{\prime} \varepsilon\right]$

$99^{\circ} \varepsilon=$

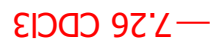

$6 L ' 6-$

96.6 -
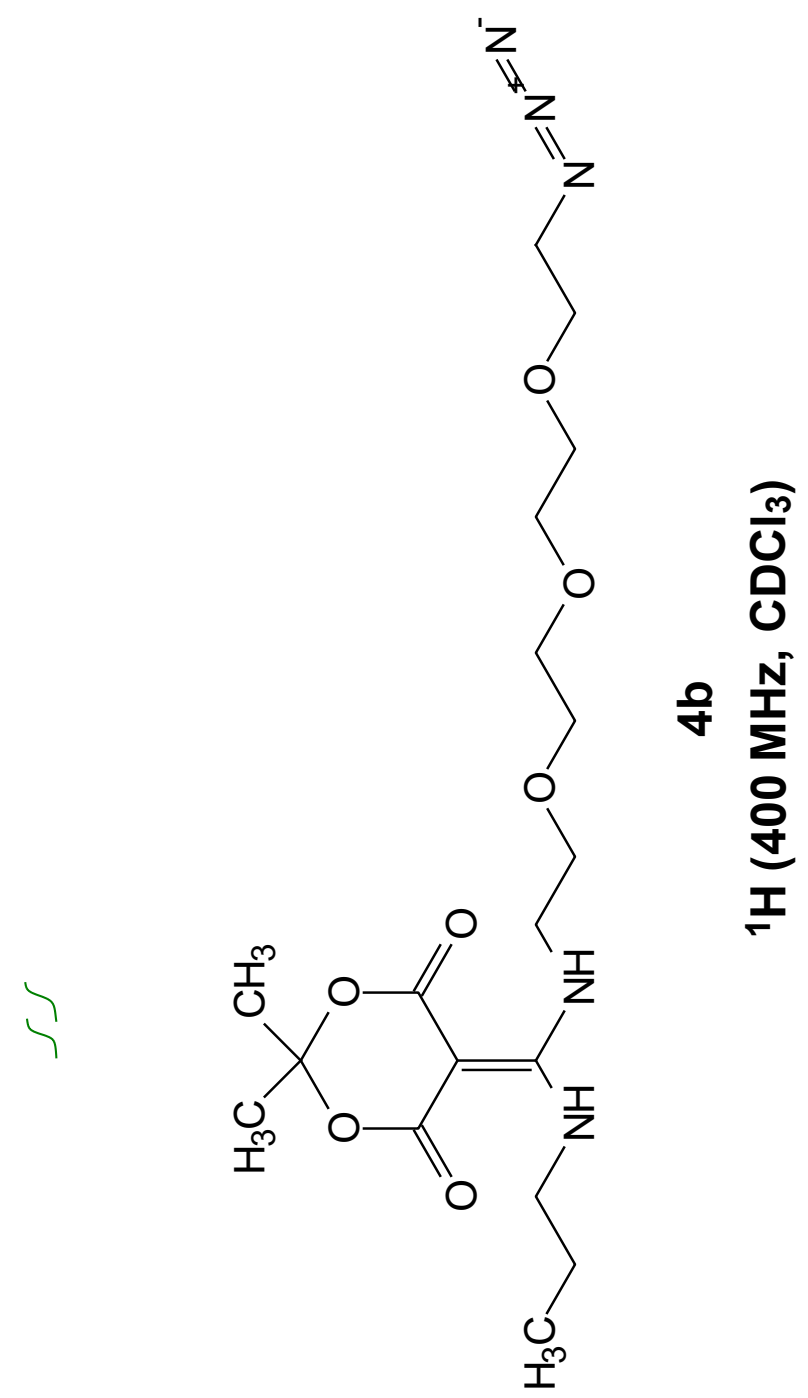
OZ'II一

Iธ'ยZ-

$80^{\circ} 92$

$\varepsilon \tau ' s t-$

$\angle Z L^{\circ} \angle t-$

S9.0S-

$+9^{\circ} 69$

$\angle 6^{\circ} 69$

$85^{\circ} 0 \angle 7$

$\left[9^{\circ} 0 \angle\right.$

$\angle 9^{\circ} 0 \angle-$

$\checkmark 8^{\circ} 0 \angle$

$98^{\circ} 0 \angle$

$20^{\circ} \rightarrow \angle$

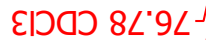

हागऽ 0I'LL-

हागव てt:LL

$\angle 6^{\circ}$ TOI-

II't9I-

ZS'99I-

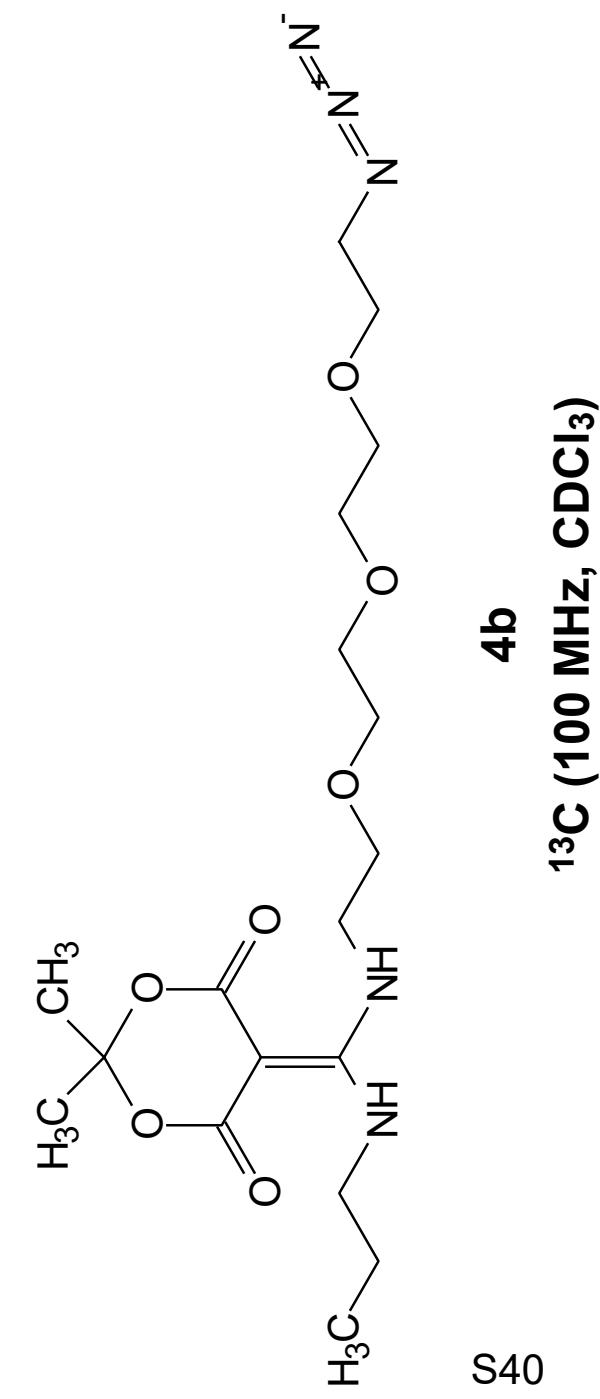

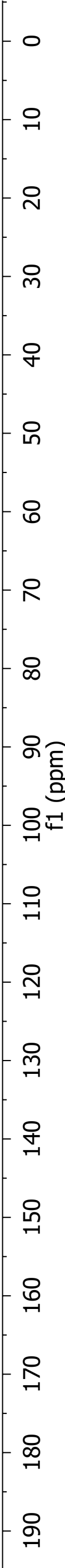


$8 I^{\prime} \mathrm{I}-$

SE'T-

ZS'I-

$\angle 9^{\prime}$ Z-

乙I'

IIS-

ع) 9น'L-

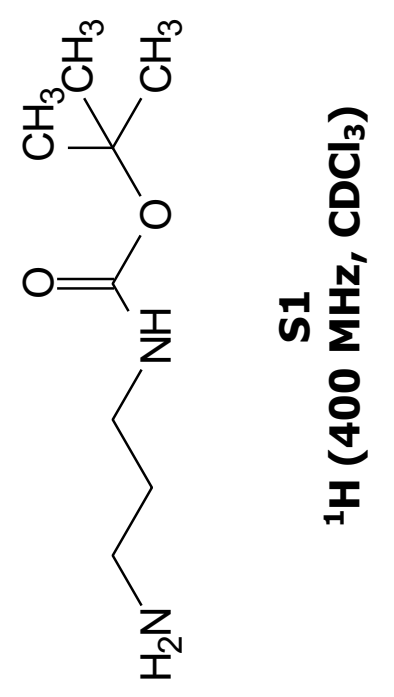




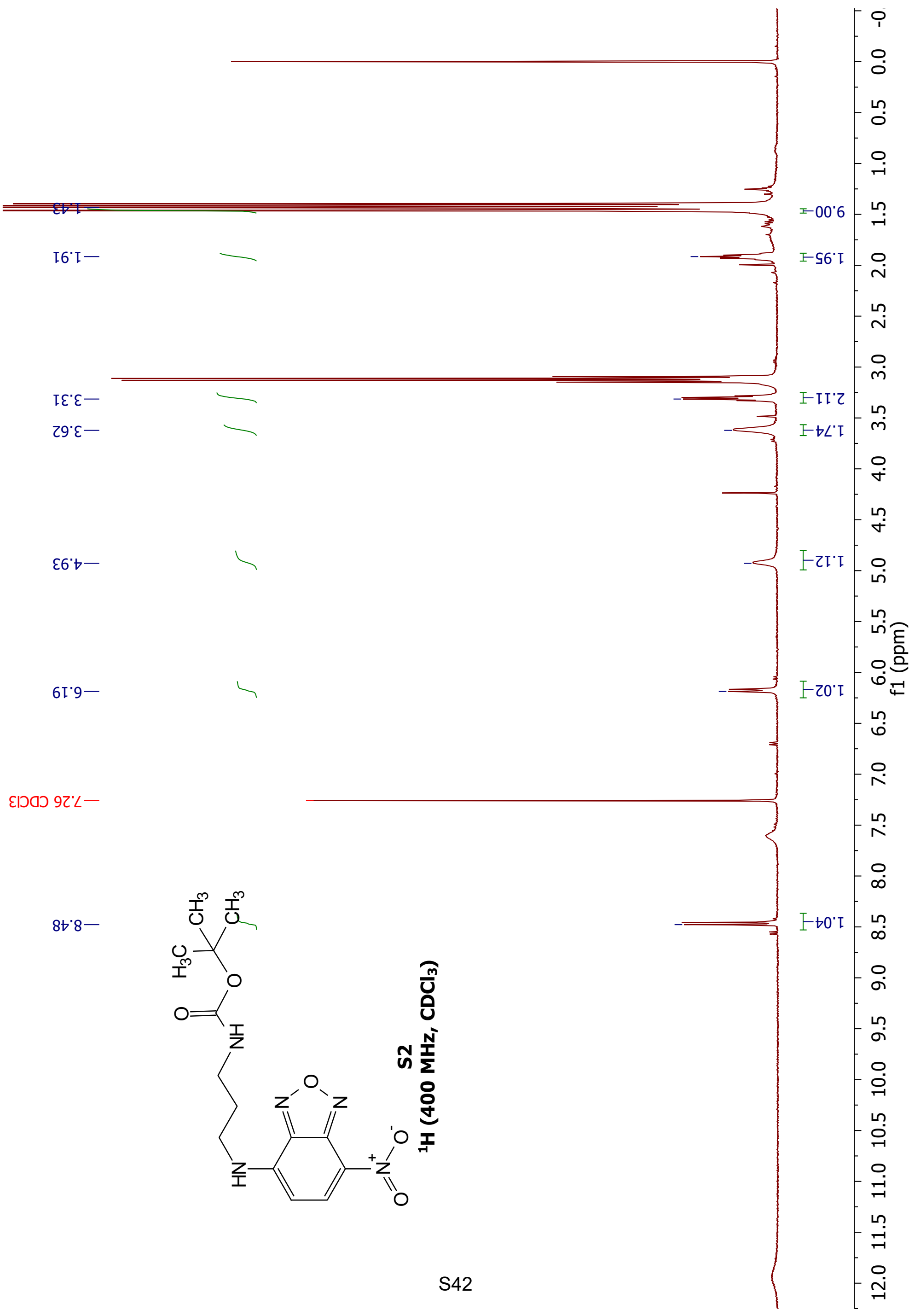




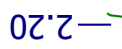

I乙' $\varepsilon-$

乙L' $\varepsilon-$

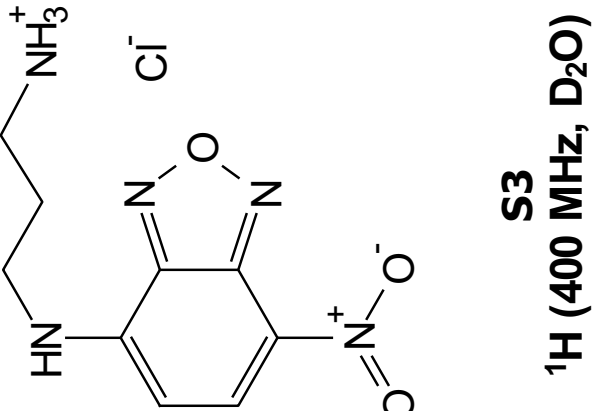

$\angle t^{\circ} 8-$

Оิ

h $\frac{\text { N }}{\Sigma}$

8요 
$t L ' I=$

$$
\begin{aligned}
& \text { Sでー- } \\
& \text { 09'て- }
\end{aligned}
$$

89' $\varepsilon-$ † ${ }^{\circ} \varepsilon-$

SZ'96ह'9-

عાગ 9ح'L—

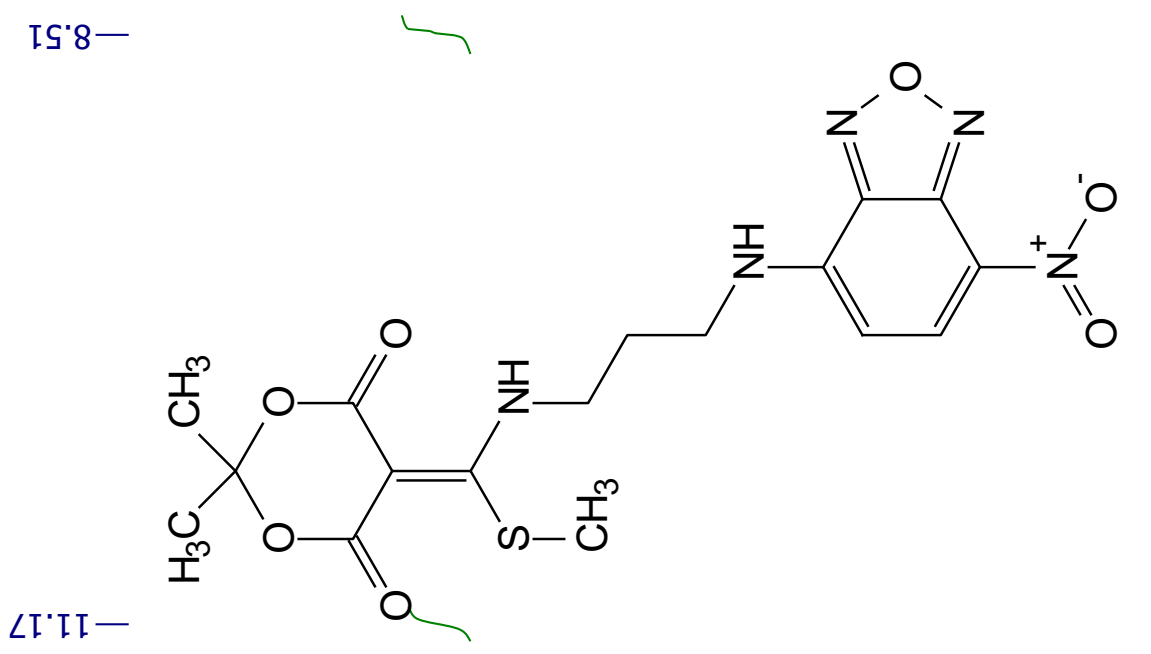

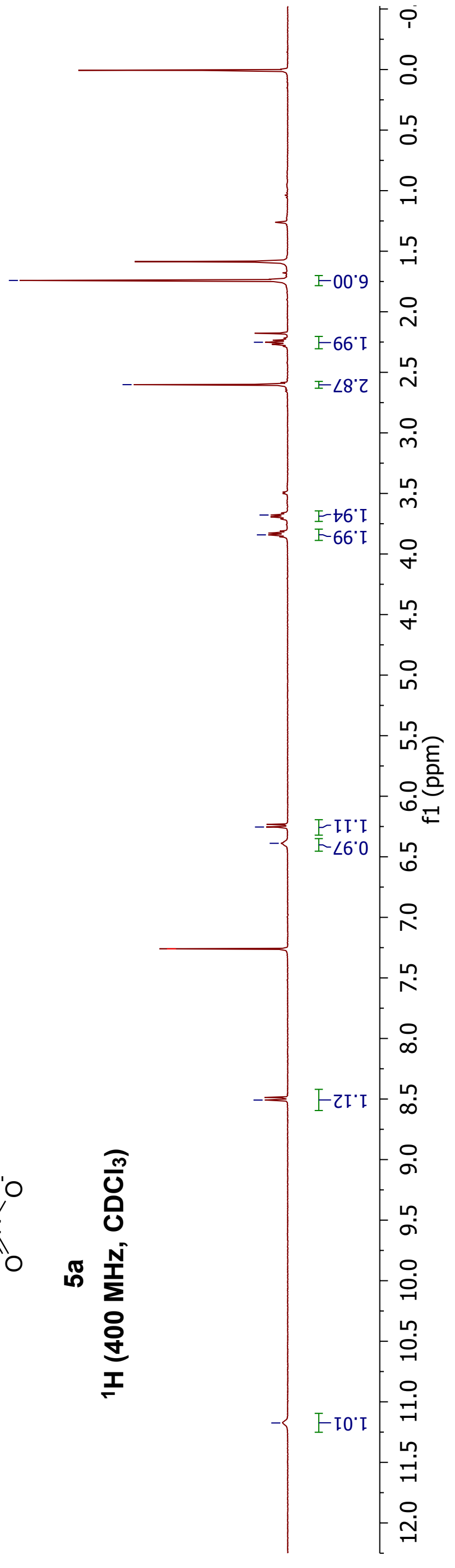


$\angle Z \cdot 9 Z-$

เ9. $\angle 乙^{\top}$

ยโ'โย-

OSWO $9 \varepsilon^{\prime} 6 \varepsilon$

OSWO $\angle S^{\prime} 6 \varepsilon$ ]

OSWO $8 \angle L^{\circ} G \varepsilon$

OSWO $66^{\circ} 6 \varepsilon$ -

OSWO 0Z"0t-

OSWO It.0t-

OSWO T9.0t-

t0 It

$\varepsilon 6^{\prime} \varepsilon \succ^{\prime}$
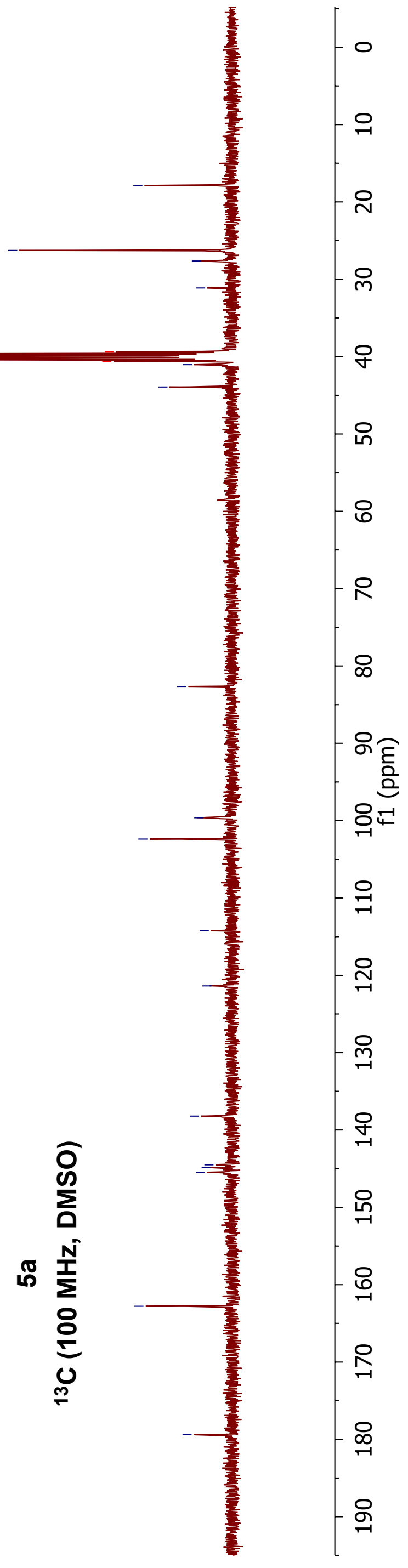

Sで๋II-

$\angle E^{\prime} I Z I-$

0Z'8EI -

$0 S^{\circ} t \circ \mathrm{L}$

$88^{\circ} t t 5 \frac{1}{5}$
$9 t^{\circ}$ StI

(1)

$6 L 29 I-\frac{m}{U}$

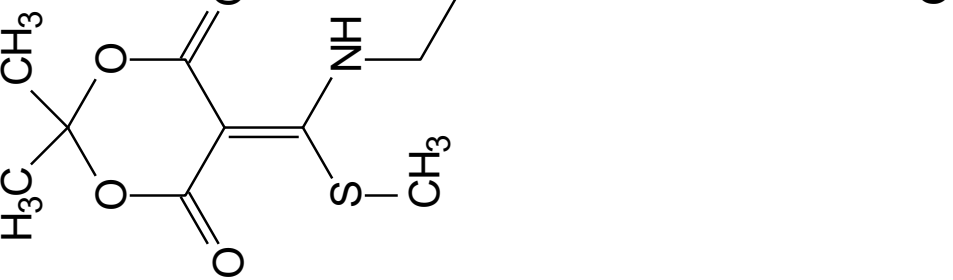

$0 t^{\circ} 6 \angle I-$ 

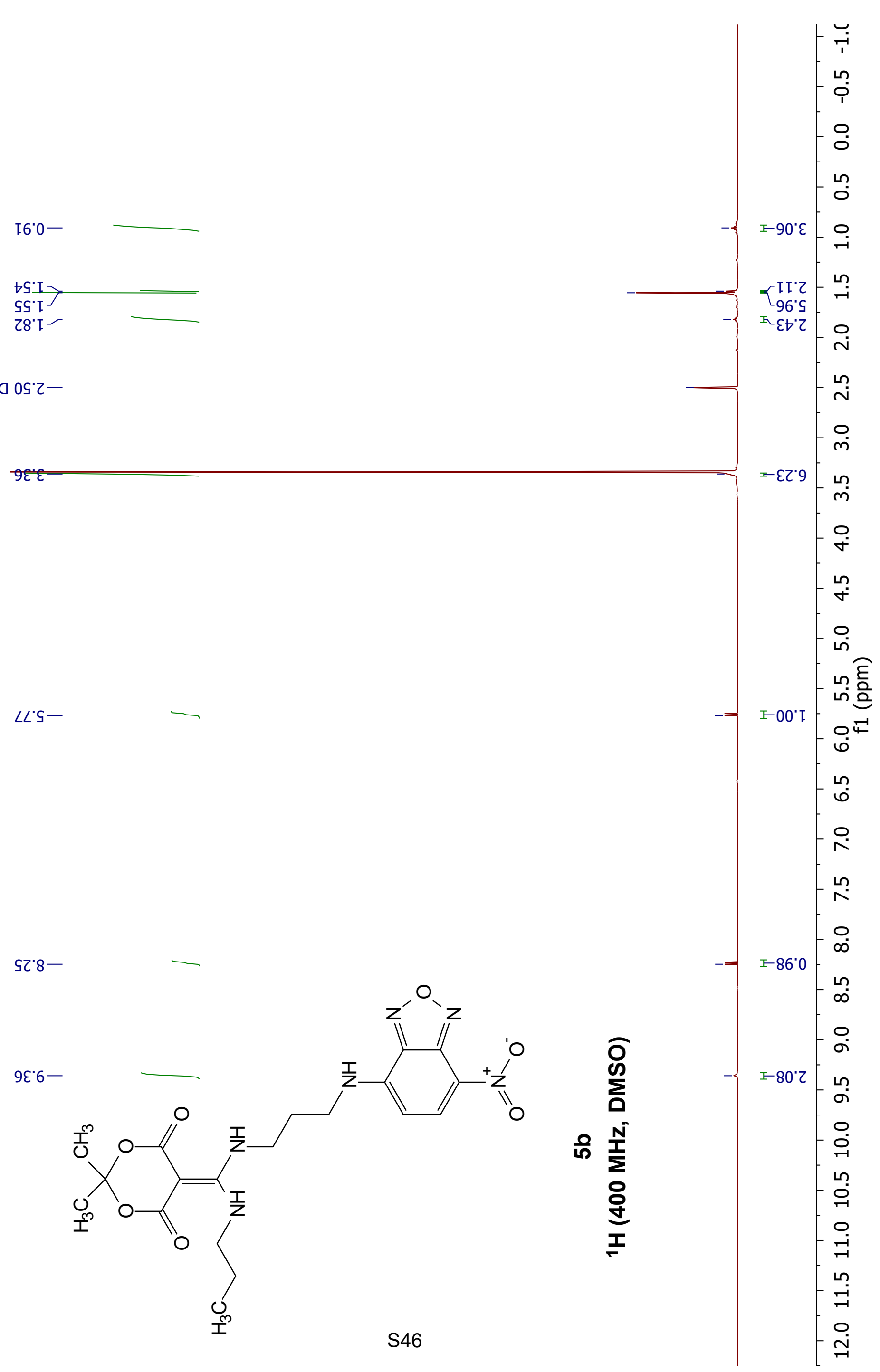
00.II-

$0 L ' 8 \mathrm{I}-$

Z9'SZ-

$\downarrow 6^{\circ} \angle \varepsilon_{7}$

OSWO Z0"6ع

OSWO 6I"6ع

OSWO SE"6E]

oswurs
I9.6ह

OSWO 69"6ع-

$8 \angle{ }^{\circ} 6 \varepsilon$

OSWO $58^{\circ} 6 \varepsilon$ -

$56^{\circ} 6 \varepsilon-$

OSWO Z0"0t

tI'TL-

†S' TOI-

EI'III-

${ }^{\circ} \angle \varepsilon I-$
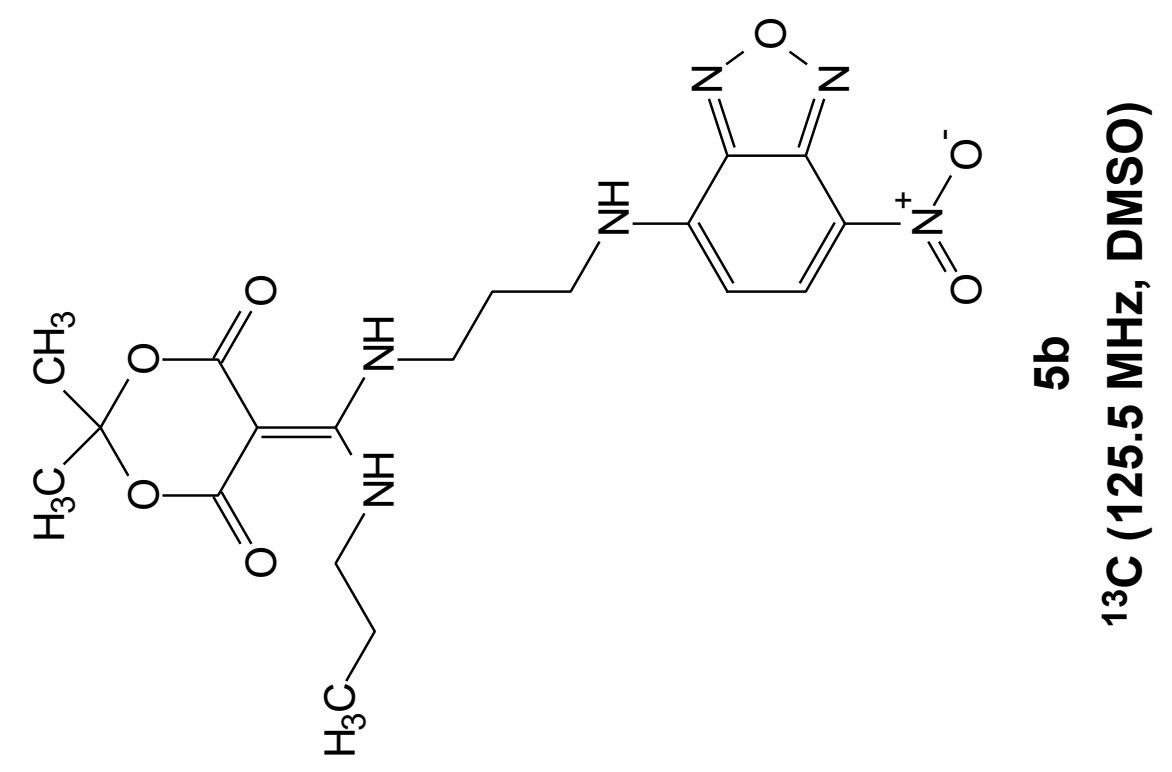


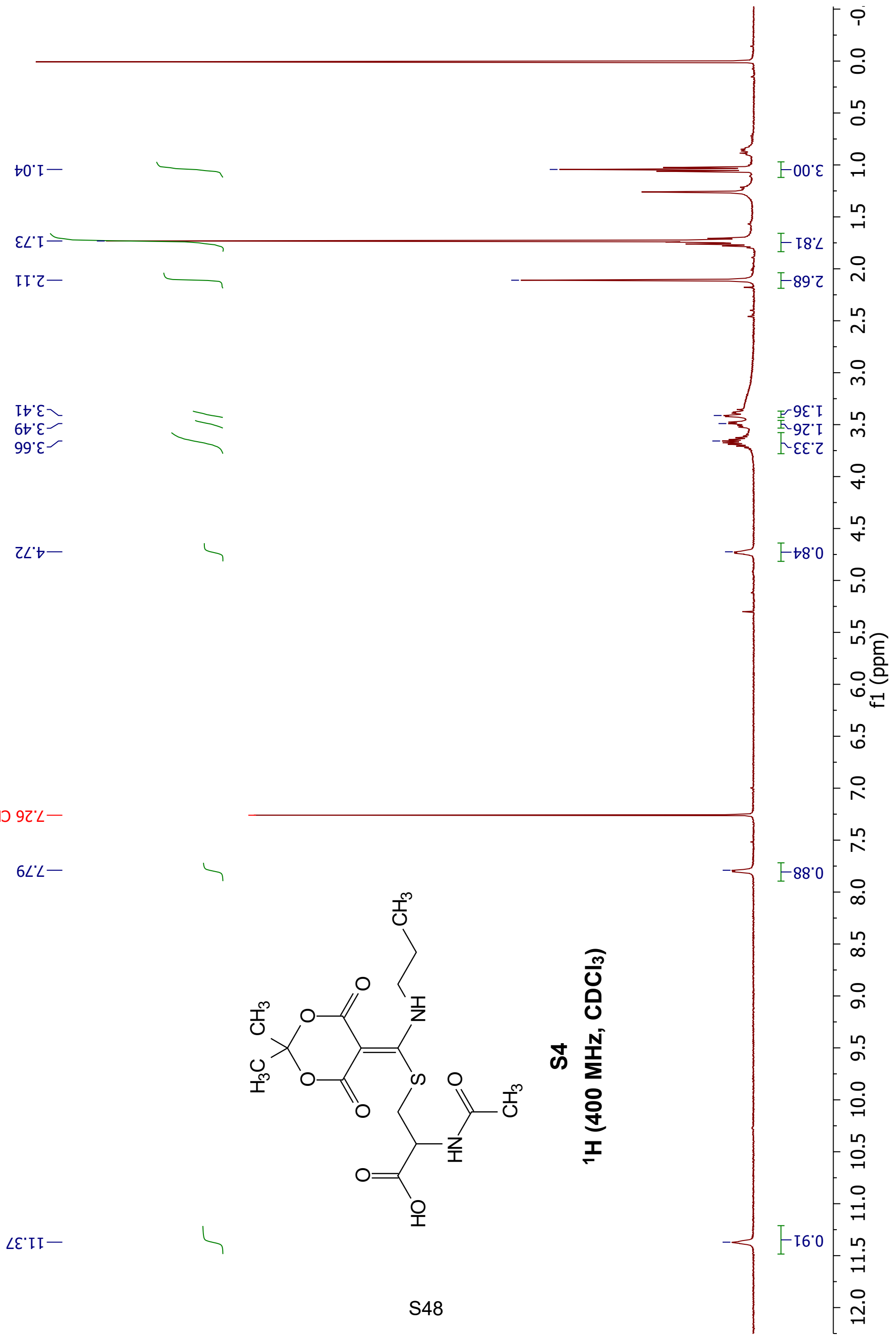


tt' II -

เ6' 22 -

てь.92-

$6 \varepsilon^{\circ} 62-$

$00^{\circ} \angle \varepsilon-$

$65^{\prime} 8 b-$

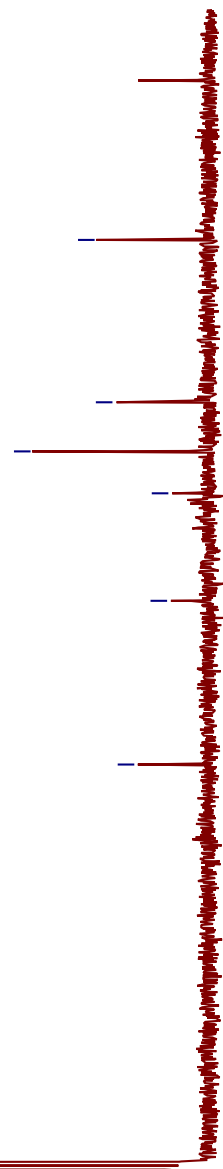

โ8'เ8-

Eเ" $\varepsilon 0[-$

$78^{\circ}+9 \mathrm{I}$

S9'Z $\angle \mathrm{I}-$

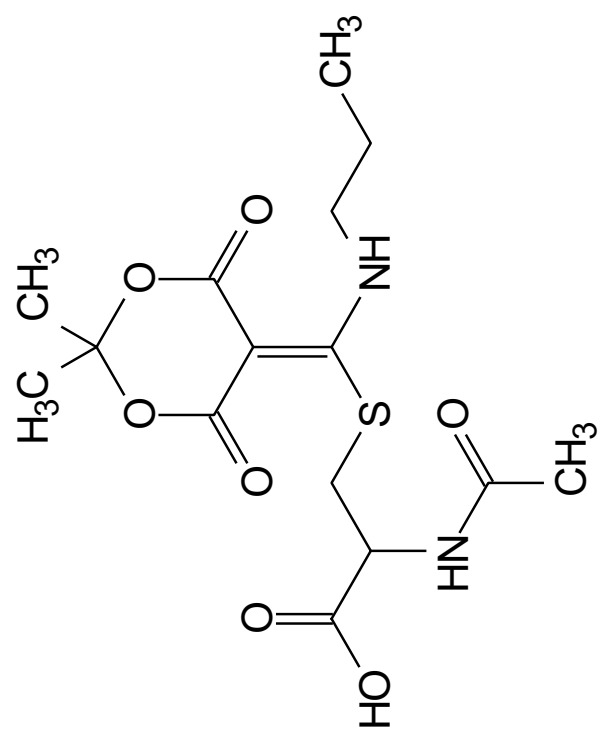

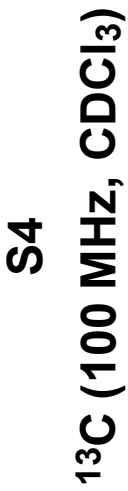

$26^{\circ} \circ \angle I-$ 